\title{
Los primeros objetos de adorno personal de la prehistoria reciente del poblado de Los Castillejos en Las Peñas de los Gitanos (Montefrío, España)
}

(1) Claudia Pau* y Juan A. Cámara Serrano*

Recibido:

31 de marzo de 2017

Aceptado:

31 de agosto de 2017

\section{Resumen}

En este trabajo exponemos los resultados de los análisis de los adornos del poblado de Los Castillejos en Las Peñas de los Gitanos (Montefrío, España) hallados durante las intervenciones arqueológicas realizadas entre 1991 y 1994 . Se incluyen los hallazgos de las fases estratigráficas 1 a 19, pertenecientes a un arco temporal que va del Neolítico Antiguo (5400 a.C.) hasta el Calcolítico Pleno (2550 a.C.). Se ha llevado a cabo el estudio morfo-tipológico, la caracterización de la materia prima y el análisis traceológico. Se han establecido seis categorías morfológicas cuya cronología se ha clarificado, lo que ha permitido definir los momentos de fabricación y uso de cada una de ellas e, indirectamente, corregir atribuciones cronológicas de algunos materiales pertenecientes a yacimientos andaluces sin secuencia estratigráfica. Por ejemplo, se ha podido proponer que muchos sepulcros megalíticos estuvieron en uso por lo menos desde el Neolítico Final. La materia prima es principalmente local pero la presencia de un adorno en marfil muestra que el poblado estaba incluido en las redes de intercambio del Mediterráneo. Se han identificado, principalmente, las últimas fases de manufactura y procesos de reparación y se han propuesto las diferentes maneras de llevar los adornos.

The first personal ornaments from the Late Prehistoric population of Los Castillejos at the Las Peñas de los Gitanos site (Montefrío, Spain)

\begin{abstract}
In this article, we present the results of the analysis of ornaments from the Los Castillejos population at the Las Peñas de los Gitanos site (Montefrío, Spain). These objects were recovered during archaeological excavations undertaken between 1991 and 1994. The items belong to stratigraphic phases 1 through to 19 and range from the Early Neolithic (5400 BC) to the Middle Chalcolithic (2550 BC). We carried out morpho-typological studies, raw material characterization, and traceology. On this basis, six morphological categories were defined. In turn, this has allowed us to date the manufacture of each of these types,
\end{abstract}

Palabras clave

Neolítico

Calcolítico

Andalucía

Objetos de adorno personal

Materia prima

Traceología
Keywords

Neolithic

Chalcolithic

Andalusia

Personal ornaments

Raw material

Traceology

* Departamento de Prehistoria y Arqueología, Universidad de Granada. Campus Universitario de "Cartuja" s/n. Granada, España. E-mail: claupau@ugr.es; jacamara@ugr.es 
and thereby to indirectly correct the dating of similar items found at other Andalusian sites lacking a fixed stratigraphic sequence. For example, this data permits us to suggest that many of these megalithic tombs were in use from the Final Neolithic onwards. Local raw materials were predominantly used in the manufacture of these items, although the presence of an ivory ornament demonstrates that the site was a part of Mediterranean exchange networks. We have mainly highlighted the final stages of manufacture as well as repair processes; we have also proposed way in which these ornaments might have been worn.

\section{Introducción}

El poblado de Los Castillejos está ubicado en Andalucía oriental (España) en el paraje de las Peñas de los Gitanos, en el término municipal de Montefrío (Granada) (Figura 1). Se sitúa sobre una terraza delimitada por grandes escarpes con una altura de 1.050 m sobre el nivel del mar (Arribas y Molina, 1977, pp. 9-12). Los Castillejos forman parte de un conjunto arqueológico más amplio, ya que el área fue habitada desde la prehistoria reciente hasta época medieval. El conjunto fue declarado Bien de Interés Cultural en el año 1996 e incluye cuevas, abrigos, poblados y necrópolis entre las cuales destaca la necrópolis megalítica relacionada con el hábitat prehistórico situado en los Castillejos (Cámara, Afonso y Molina, 2016, pp. 94-109).

El conjunto fue dado a conocer en 1868 por M. de Góngora y Martínez (Góngora Martínez, 1991). A principios del siglo XX, M. Gómez-Moreno hizo un análisis de la zona recogiendo material del poblado, y realizó un estudio sobre las necrópolis megalíticas (Gómez, 1907, 1949). En 1926, C. de Mergelina llevó a cabo excavaciones arqueológicas en la necrópolis, en el poblado de los Castillejos y en algunas cuevas, publicando los resultados sólo tras la Guerra Civil (De Mergelina, 1941-1942, 1946). En los años treinta del siglo XX, Georg y Vera Leisner visitaron la zona para incluir la necrópolis en su catálogo sobre las tumbas megalíticas del Sur de la Península Ibérica (Leisner y Leisner, 1943). Sólo en 1946 M. Tarradell profundizó en los niveles prehistóricos del poblado de Los Castillejos, además de excavar en las inmediatas Cueva Alta, Cueva de las Cabras, Cueva de la Alondra, Raja de la Mora y Cueva Negra (Tarradell, 1947, 1952). En el marco del Congreso de Arqueología de Campo, promovido por la Comisaría General de Excavaciones Arqueológicas y celebrado en Granada en 1953, se realizó por parte de E. Van Giffen la excavación de un dolmen en el Hoyón de la Virgen (actualmente El Castellón) y se hicieron algunos cortes en el poblado de los Castillejos. Sin embargo estos trabajos nunca se publicaron.

Entre 1971 y 1974 tuvieron lugar las intervenciones del Departamento de Prehistoria y Arqueología de la Universidad de Granada que, además de proceder a la limpieza de varios dólmenes, gracias a nuevos cortes en el poblado, determinaron una amplia secuencia estratigráfica desde el Neolítico de la denominada Cultura de las Cuevas hasta la introducción de los primeros elementos propios de la Edad del Bronce Inicial (Arribas y Molina, 1977, 1978, 1979). En los años 90 del siglo XX la Universidad de Granada realizó nuevos trabajos en el yacimiento en los que, además de proceder a actividades de conservación y difusión, se pudo definir con mayor claridad la secuencia de ocupación del yacimiento, dividida en 24 fases estratigráficas desde el Neolítico Antiguo Avanzado (5400-5000 a.C.) hasta el Bronce Antiguo Inicial (1900-1800 a.C.) (Afonso et al. 1996; Cámara, Molina y Afonso, 2005; Cámara et al., 2016; Ramos, Afonso, Cámara, Molina y Moreno, 1997).

A partir de las dataciones radiocarbónicas realizadas, su calibración y su comparación con dataciones por termoluminiscencia, se ha podido definir un hiato de unos 400 años en los siglos centrales del V Milenio a.C. entre el Neolítico Medio y el Tardío (Molina et al., 2017). 


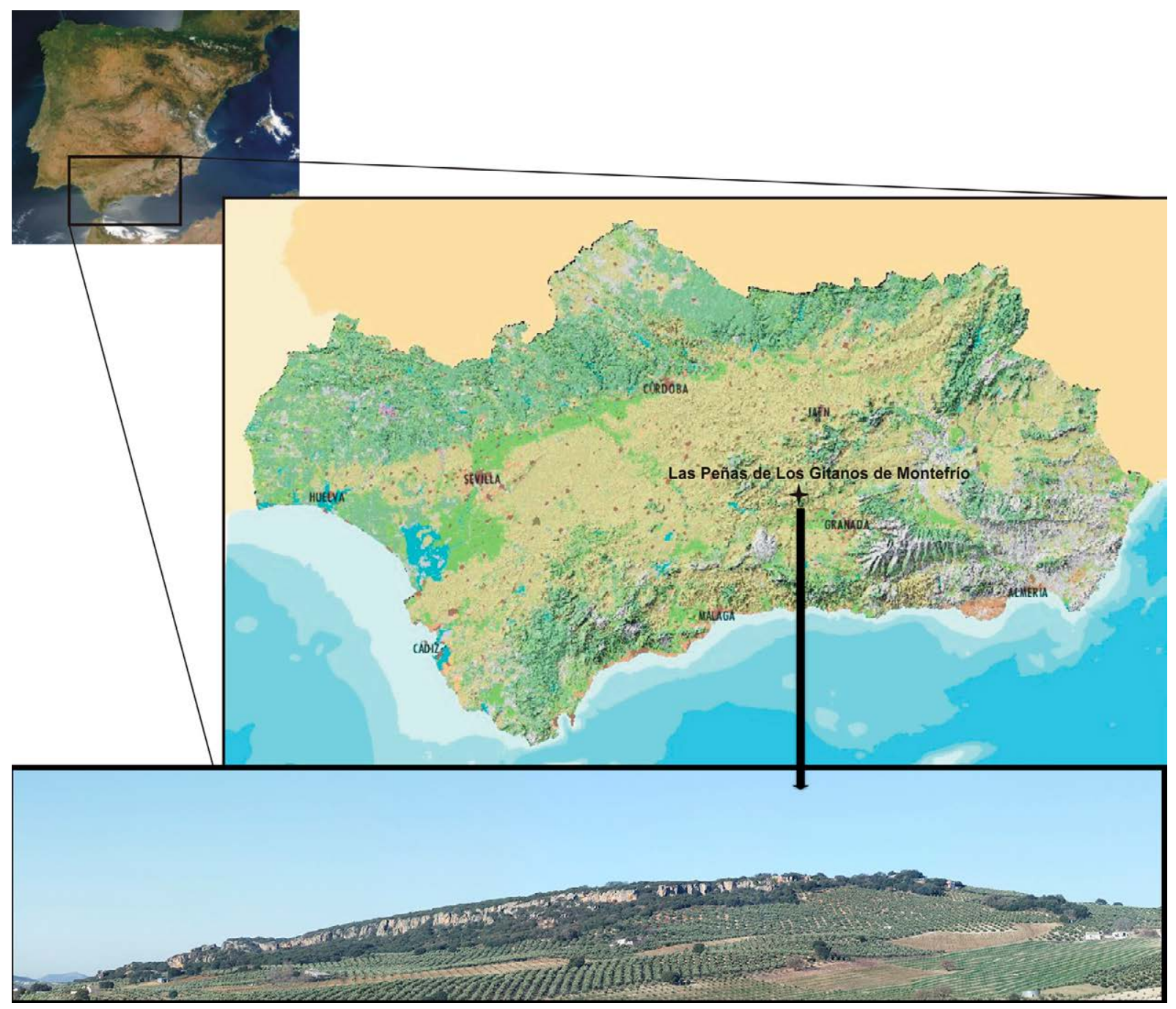

Figura 1. Panorámica del yacimiento de Los Castillejos de Montefrío (Foto J. A. Afonso Marrero).

Nuestro estudio se centra en el material ornamental recuperado en los niveles situados entre la fase 1 y la 19, correspondientes a los periodos I y VI, del Neolítico Antiguo al Calcolítico Pleno, datados entre el 5400 y el 2550 a.C. (Tabla 1).

Nuestros objetivos serán: 1) presentar a la comunidad científica todo el conjunto del material ornamental; 2) elaborar una clasificación tipológica de los ornatos; 3 ) definir las materias primas utilizadas para confeccionarlos; 4) evaluar los procesos de trabajo implicados en la realización de los objetos de adorno y la posible existencia de especialización artesanal en la realización de una o varias clases de materiales; 5) determinar cómo se llevaban los adornos y las condiciones de uso de éstos en la remarcación de la diferenciación social; 6) estimar la variabilidad de los adornos en el tiempo y, a través de la comparación con otras piezas andaluzas, sugerir variaciones espaciales y posibles contactos.

\section{Antecedentes}

En el ámbito europeo se han realizado varios trabajos dedicados a los objetos de adorno personal (entre otros Álvarez Fernández, 2006; Barciela, 2008; Bonnardin, 2009; López, 


\begin{tabular}{|c|c|c|c|c|}
\hline \multicolumn{3}{|l|}{ Períodos } & \multirow{2}{*}{$\begin{array}{l}\text { Cronología } \\
\text { (5400-5000 a.C.) }\end{array}$} & \multirow{2}{*}{$\begin{array}{l}\text { Fases estratigráficas } \\
1,2,3,4 a, 4 b, 5,6\end{array}$} \\
\hline Neolítico Antiguo & & 1 & & \\
\hline \multirow[t]{2}{*}{ Neolítico Medio } & & II & (500o-488o a.C.) & $7,8,9,10 a, 10 b, 11 a, 11 b$ \\
\hline & & & (4880-4400 a.C.) & \\
\hline \multirow{2}{*}{ Neolítico Reciente } & Neolítico Tardío & III & (4400-360o a.C.) & $12,13,14$ \\
\hline & Neolítico Final & IV & (360o-3300 a.C.) & $15,16^{\mathrm{a}}$ \\
\hline Cobre Antiguo & & V & (3300-3000 a.C.) & $16 \mathrm{~b}, 17$ \\
\hline Cobre Pleno & & VI & (3300-2550 a.C.) & 18,19 \\
\hline
\end{tabular}

Tabla 1. Cronología del yacimiento de Los Castillejos en la Peña de los Gitanos en Montefrío (Granada).

2011; Maicas, 2007; Oliva, 2015; Pascual, 1998; Pau, 2016; Taborin, 2004; Vanharen y D’Errico, 2001). Se trata de estudios tipológicos, tecnológicos y análisis funcionales que se enfocan habitualmente en objetos de adorno de un determinado yacimiento, región o área geográfica y en un periodo específico o, en algunos casos, se ocupan de una única categoría de adornos confeccionados en el mismo soporte.

En el caso del yacimiento de Los Castillejos, sólo recientemente se han realizado estudios específicos de objetos de adorno personal. En concreto se han analizado los artefactos hallados por el Departamento de Prehistoria y Arqueología de la Universidad de Granada durante las excavaciones de los años 70 del siglo XX (Altamirano, 2013; Pau, 2016), y se ha realizado una breve y parcial descripción de los materiales neolíticos y calcolíticos de las excavaciones de los años 90 del siglo XX (Pau, 2011; Pau, 2016). Los materiales, no incluidos aquí, pertenecientes a periodos más recientes, sí han sido analizados en profundidad en trabajos anteriores (Pau, 2016; Pau y Molina, 2015).

\section{Materiales y métodos}

En el presente trabajo se han estudiado los objetos de adorno hallados durante las intervenciones arqueológicas de los años 90 del siglo XX en niveles correspondientes a las fases estratigráficas 1 a 19. Estos artefactos pertenecen a un amplio periodo cronológico y cultural que comprende desde el Neolítico Antiguo (5400 a.C.) hasta el Cobre Pleno (2550 a.C.).

Se trata de un total de 162 objetos de adorno personal confeccionados en materia dura animal (material malacológico, hueso y marfil) y en material lítico. Se ha realizado un estudio morfológico y morfométrico de los objetos de adorno, lo que ha permitido proponer una clasificación tipológica compleja. Todos los artefactos han sido dibujados, fotografiados y escaneados. Las imágenes han sido recogidas en láminas a escala 1:1 y con un calibre digital se han podido registrar las medidas en una base de datos. Concretamente, de los fragmentos de brazaletes en piedra se han medido la anchura y el grosor. Además, con cálculos trigonométricos, se han reconstruido aproximadamente las medidas de los diámetros interiores que tenían que poseer las piezas completas, siguiendo un método similar al adoptado por otros investigadores (Martínez, 2010).

Los objetos en materia dura animal han sido examinados macroscópica y microscópicamente y se han realizado comparaciones entre el material arqueológico y colecciones privadas y públicas de hueso de varias especies de animales. Por otro lado, la nomenclatura que se ha utilizado para la denominación de las especies de 
conchas ha sido homogeneizada con la base de datos CLEMAN. Finalmente, se han consultado textos generales (Saunders, 1991) y específicos de la zona estudiada (Gofas, Moreno y Salas, 2011). Sobre el material pétreo se han empleado técnicas no destructivas que nos han permitido caracterizar y distinguir con criterios diagnósticos las diferentes materias primas gracias a observaciones colorimétricas y microscópicas, completadas con análisis XRF y PIXE-PIGE realizados en el Centro de Instrumentación Científica de la Universidad de Granada. Se ha realizado un análisis traceológico para determinar las técnicas de fabricación y el uso de los objetos de adorno, examinando los artefactos con la lupa binocular y microscopio electrónico de barrido (SEM).

\section{Resultados}

\section{Estudio tipológico}

\section{Clasificación}

Los objetos de adorno estudiados (162 artefactos) se han agrupado en seis categorías tipológicas (Barge, 1982; Bonnardin, 2009; López, 2011; Pascual, 1998; Pau, 2012; 2016, siguiendo a Barciela, 2008). Además las categorías I, II, III y V incluyen subdivisiones. En la primera se han distinguido tres grupos morfológicos y en la segunda cuatro. En la categoría III se han separado dos grupos y en el último de ellos se han distinguido dos subgrupos y tres tipos. Finalmente la categoría V ha sido dividida en dos grupos.

\section{Colgantes (categoría I)}

Se han definido como colgantes 22 artefactos (Figura 2) con una longitud mayor respecto a su anchura y con perforación en una de las extremidades.

\section{Colgantes de concha entera (grupo 1)}

Se han considerado colgantes de concha entera 10 artefactos obtenidos conservando la forma original del caparazón de diferentes moluscos marinos. Estos colgantes presentan una o más perforaciones circulares, ovales o irregulares, realizadas intencionalmente. En el caso de los gasterópodos la perforación se ha localizado en posición dorsal o apical. (Neolítico Antiguo: 6150, 614255b, 612949, 613853; Neolítico Medio: 613406, $611653,611357,611283,614165$ y 6112829$)$.

\section{Colgantes rectangulares (grupo 2)}

Hemos clasificado como colgantes rectangulares a cinco artefactos que presentan una forma rectangular o sub-rectangular, con las aristas redondeadas o rectas, sección general plana y perforación circular con sección cilíndrica o cónica, realizada en uno de los dos lados cortos. (Neolítico Antiguo: 613854 y 612579; Neolítico Medio: 69508; Neolítico Tardío: 67595 y 68377).

\section{Colgantes de lágrima (grupo 3)}

Hemos definido como colgantes de lágrima a siete artefactos que imitan la forma de los caninos atrofiados de ciervo. Son elementos que presentan sus dos caras de forma oval o elíptica con sección abultada en la extremidad opuesta a la perforación. Se trata de pequeños artefactos manufacturados en material lítico. (Neolítico Medio: 610683, 69748, 69678, 69308, 69544; Neolítico Tardío: 68953-2, 68977). 


\section{CATEGORÍA I}

\section{GRUPO 1}

Neolítico Antiguo

Neolítico Medio

Fase 0
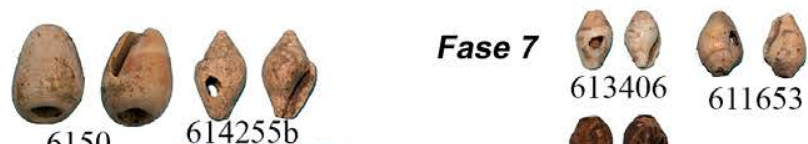

Fase 4
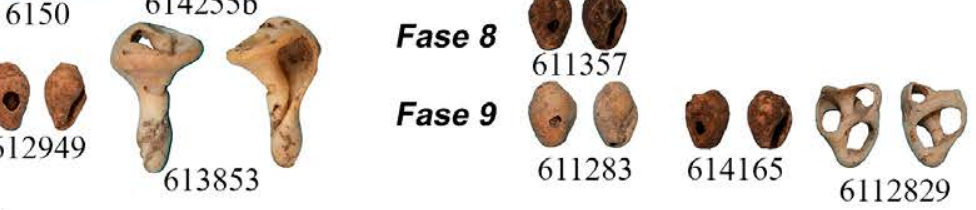

GRUPO 2

\section{Neolítico Antiguo}

Fase 2

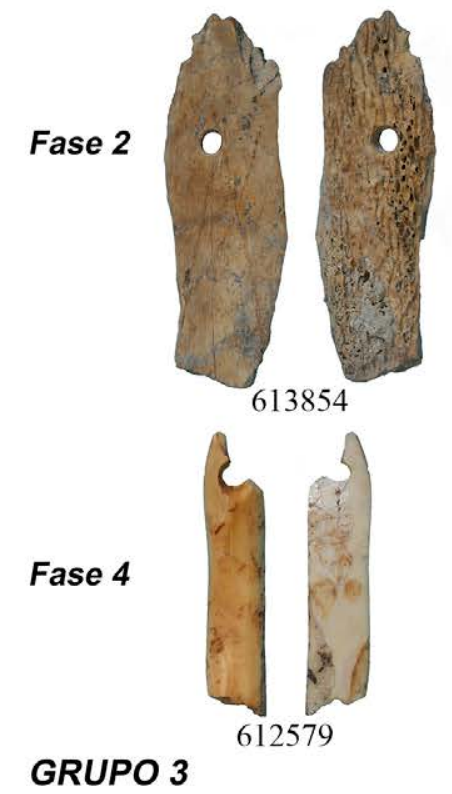

Neolítico Medio

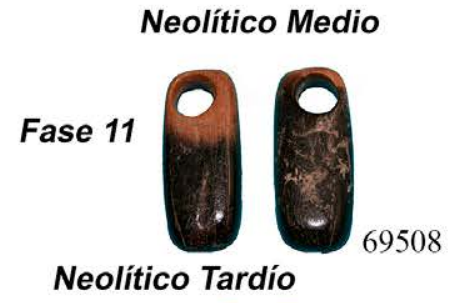

Fase 13

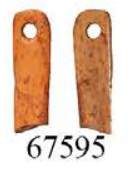

Fase 14
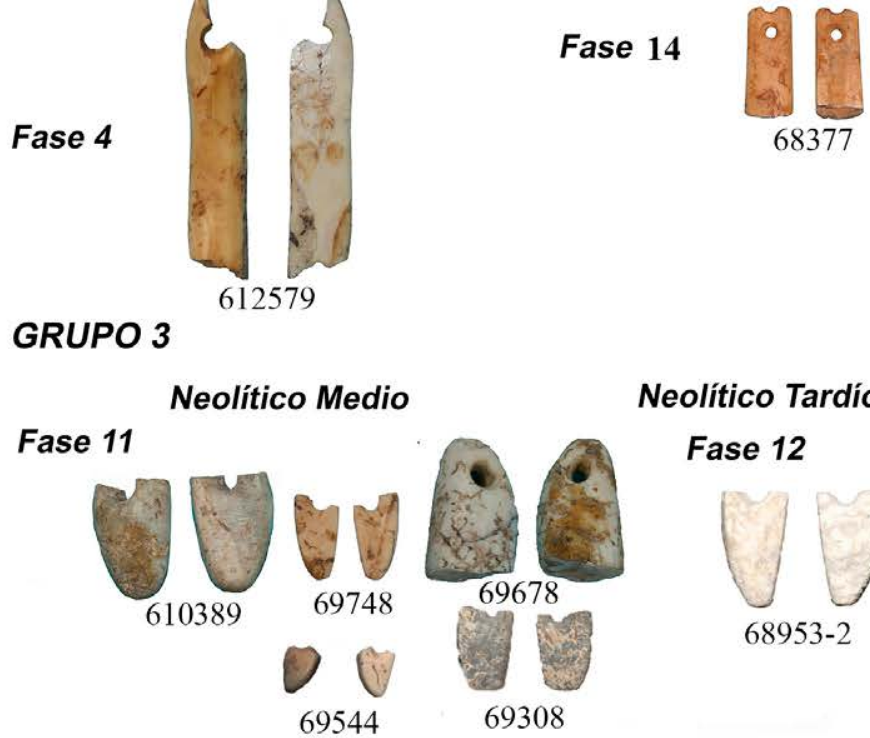

Neolítico Tardío

Fase 12

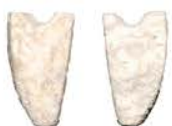

68953-2

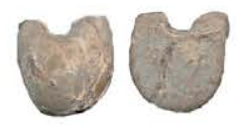

68977

69544 $4 \mathrm{~cm}$

Figura 2. Colgantes de concha entera: Neolítico Antiguo: 6150, 614255b, 612949, 613853, Neolítico Medio: 613406, 611653, 611357, 611283, 614165 y 6112829; Colgantes rectangulares: Neolítico Antiguo: 613854 y 612579, Neolítico Medio: 69508, Neolítico Tardío: 67595 y 68377 . Colgantes de lágrimas: Neolítico Medio: 610683, 69748, 69678, 69308, 69544 Neolítico Tardío: 68953-2 y 68977.

\section{Cuentas (categoría II)}

Se han definido como cuentas 14 artefactos (Figura 3) que presentan una anchura superior o igual a la altura y una perforación central, normalmente única, el eje de la cual corresponde con el de rotación de la pieza. 


\section{CATEGORÍA II}

\section{GRUPO 1}

\section{Neolítico Final}

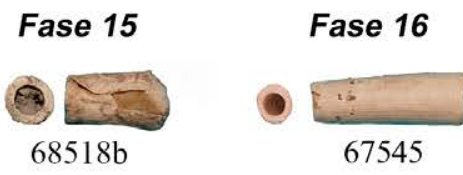

GRUPO 2

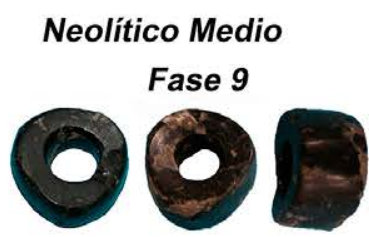

611032

Fase 10

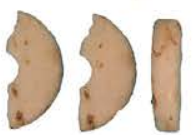

610180a

GRUPO 3

\section{Neolítico Antiguo \\ Fase 3}

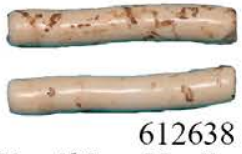

Neolítico Medio

Fase 11

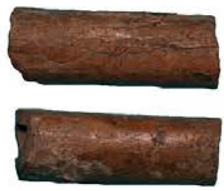

6106829
Neolítico Tardío

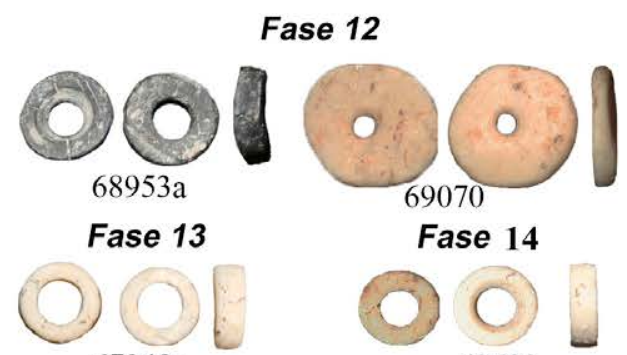

$67948 \mathrm{a}$

63682

Neolítico Final

Fase 15

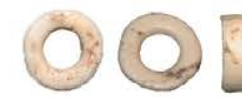

68517

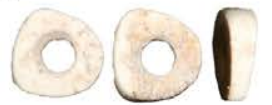

$68502 \mathrm{c}$
GRUPO 4

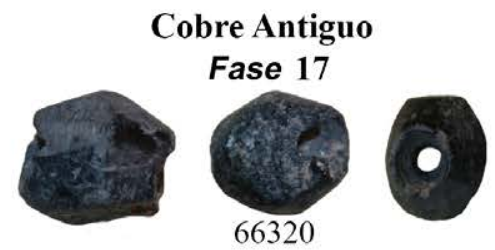

Cobre Pleno

Fase 18
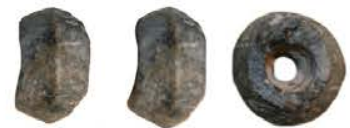

62894

Figura 3. Cuentas de concha entera: Neolítico Final: 68518b y 67545; Cuentas discoidales: Neolítico Medio: 611032 y 61018oa; Neolítico Tardío: 68953a, 69070, 67948a, 63682, Neolítico Final: 68517 y 68502c. Cuentas cilíndricas: Neolítico Antiguo: 612638 y Neolítico Medio: 610682. Cuentas bitroncocónicas: Cobre Antiguo: 66320, Cobre Pleno: 62894.

\section{Cuentas de concha entera (grupo 1)}

Las cuentas de concha entera (dos artefactos) son adornos obtenidos conservando la forma anatómica natural del caparazón de moluscos marinos (escafópodos) y aprovechando su perforación natural. Se utilizaron fragmentos de concha regularizados 
por la erosión marina y, a veces, se eliminó el extremo con la técnica del aserrado (Neolítico Final: 68518b y 67545).

\section{Cuentas discoidales (grupo 2)}

Se trata de pequeños elementos de forma discoidal (ocho artefactos) de sección plana o ligeramente plano-cóncava o plano-convexa, con dimensiones variables y con una perforación central cilíndrica o troncocónica transversal a su eje máximo (Neolítico Medio: 611032 y 610180a; Neolítico Tardío: 68953a, 69070, 67948a, 63682; Neolítico Final: 68517 y $68502 c)$.

\section{Cuentas cilíndricas (grupo 3)}

Las cuentas cilíndricas o tubulares (dos artefactos) presentan una perforación central cilíndrica, a veces con sección ligeramente ovalada, en sentido longitudinal a su eje máximo. (Neolítico Antiguo: 612638; Neolítico Medio: 610682).

\section{Cuentas bitroncocónicas (grupo 4)}

Las cuentas bitroncocónicas son elementos de forma bitroncocónica y sección circular o oval con arista central y presentan una perforación central, de forma circular y sección cilíndrica, en sentido longitudinal a su eje máximo. (Cobre Antiguo: 66320; Cobre Pleno: 62894).

\section{Elementos anulares (categoría III)}

Son piezas que, como su nombre sugiere, se conforman a partir de un hueco central (correspondiente al volumen de la porción del cuerpo humano a la que iban destinadas) en torno al cual el objeto se presenta con sección circular, plano-convexa o rectangular. Los artefactos de esta categoría (112 elementos) se han separado en dos grupos según su diámetro interno (Figuras 4, 5, 6, 7, 8, 9, 10).

\section{$\underline{\text { Elementos anulares con diámetro interno inferior a 2,5 cm (Grupo 1) }}$}

De esta morfología sólo se ha identificado un objeto en el conjunto estudiado. Muestra un diámetro exterior mayor que el espesor de su borde y presenta un hueco central con diámetro entre los 0,9 y $2,5 \mathrm{~cm}$. Este tipo de elementos pueden tener la anchura, espesor y la sección del perímetro exterior regular o variada (Pascual, 1998, p. 152). (Neolítico Medio: 65226).

\section{Elementos anulares con diámetro entre los 4 y $10 \mathrm{~cm}$ (Grupo 2)}

En este grupo hemos situado los adornos comúnmente denominados como brazaletes. Se trata de objetos con secciones variadas y un amplio hueco interior con un diámetro entre los 4 y $10 \mathrm{~cm}$ (Pascual, 1998, p. 158). Se han dividido los artefactos de este grupo (111 elementos) en dos subgrupos diferentes según la materia prima utilizada para confeccionarlos. El subgrupo 1 incluye los brazaletes en piedra y el subgrupo 2 los que se han realizado en concha.

\section{$\underline{\text { Subgrupo } 1}$}

Los fragmentos de brazaletes de piedra presentan sección plano-convexa, subrectangular u ovalada y el diámetro interior entre los 6 y $10 \mathrm{~cm}$. Se ha dividido este subgrupo de artefactos (98 elementos) en tres tipos basándonos en la relación entre espesor y anchura. 


\section{CATEGORÍA III GRUPO 1}

\section{Neolítico Medio}

\section{Fase 8}

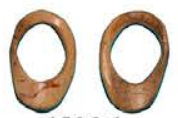

65226

GRUPO 2

\section{SUBGRUPO 1} TIPO 1

\section{Neolítico Antiguo}
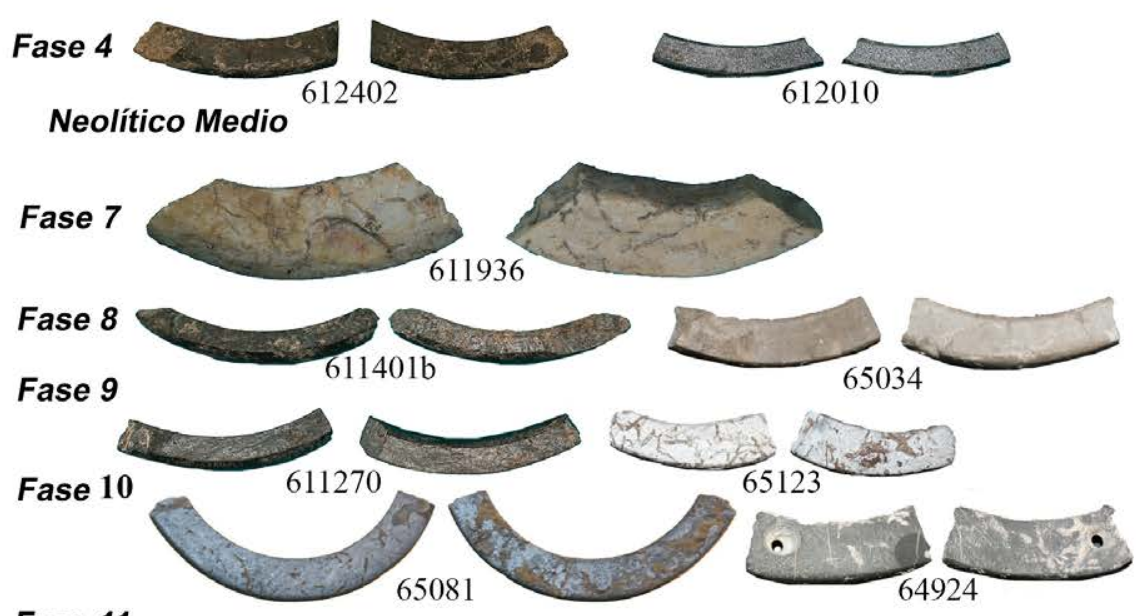

Fase 11

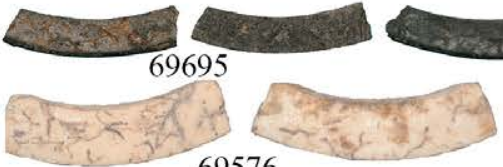

69576

69734

610440

\section{Neolítico Tardío}

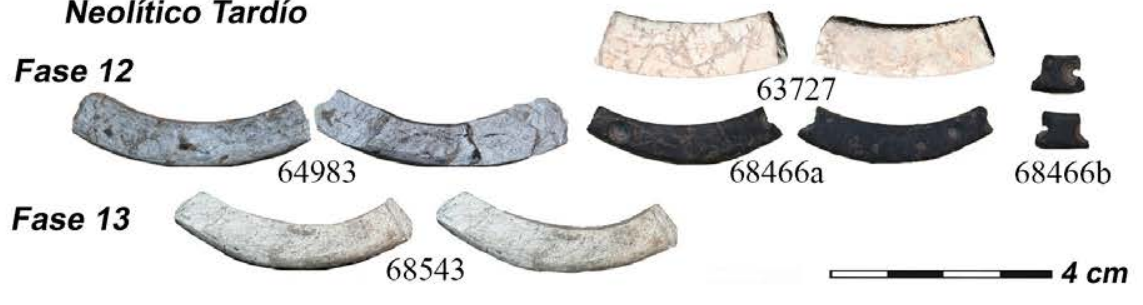

Figura 4. Elementos anulares: Grupo 1. Neolítico Medio: 65226, Grupo 2, subgrupo 1, tipo 1. Neolítico Antiguo: 612402, 612010, Neolítico Medio: 611936, 611401b, 65034, 93611270, 65123, 65081, 64924, 69695, 69734, 610440, 69576, 69639, Neolítico Tardío: 63727, 64983, 68466a, 68466b y 68543 .

\section{$\underline{\text { Tipo } 1}$}

Se han colocado en este tipo los brazaletes (19 elementos) que presentan una anchura inferior a su espesor. Su anchura se sitúa entre $0,3 \mathrm{~cm}$ y $1 \mathrm{~cm}$ y su espesor entre 0,7 y 2 $\mathrm{cm}$. Muestran sección plana de forma subrectangular, siendo de hecho adornos muy estrechos (Neolítico Antiguo: 612402, 612010; Neolítico Medio: 611936, 611401b, 


\section{CATEGORÍA III}

\section{GRUPO 2 \\ SUBGRUPO 1}

TIPO 2

\section{Neolítico Antiguo}

Fase 2

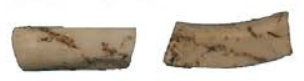

613998
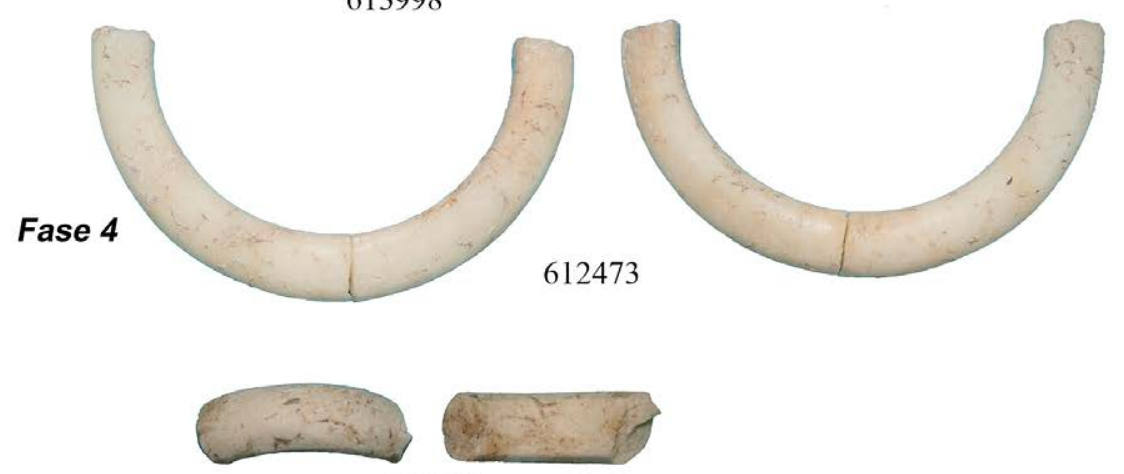

611990

\section{Neolítico Medio}

\section{Fase 9}

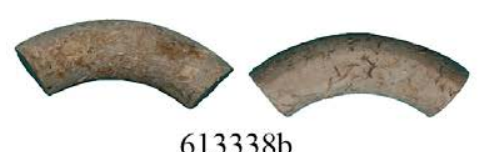

$613338 b$

Fase 10

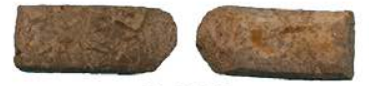

610233

$4 \mathrm{~cm}$

Figura 5. Elementos anulares: Neolítico Antiguo: 613998, 612473, 61199o, Neolítico medio: MF94613338b y MF93610233.

65034, 93611270, 65123, 65081, 64924, 69695, 69734, 610440, 69576, 69639; Neolítico Tardío: 63727, 64983, 68466a, 68466b, 68543).

\section{Tipo 2}

Se ha adscrito a este tipo un grupo reducido de elementos anulares (cinco elementos) que presentan casi las mismas medidas de anchura y espesor y la sección ovalada (anchura y espesor entre los 0,5 y $1 \mathrm{~cm}$ ). (Neolítico Antiguo: 613998, 612473, 611990; Neolítico Medio: 613338b, 610233).

\section{$\underline{\text { Tipo } 3}$}

Forman el tipo 3 aquellos brazaletes (74 elementos) que presentan una anchura superior a su espesor. Su anchura oscila entre 1 y $5 \mathrm{~cm}$ y su espesor entre los 0,4 y $1 \mathrm{~cm}$, y muestran sección plano-convexa. (Neolítico Antiguo: 614082; 613003, 612900, 612767, 


\section{CATEGORÍA III}

\section{GRUPO 2 \\ SUBGRUPO 1 \\ TIPO 3}

\section{Neolítico Antiguo}

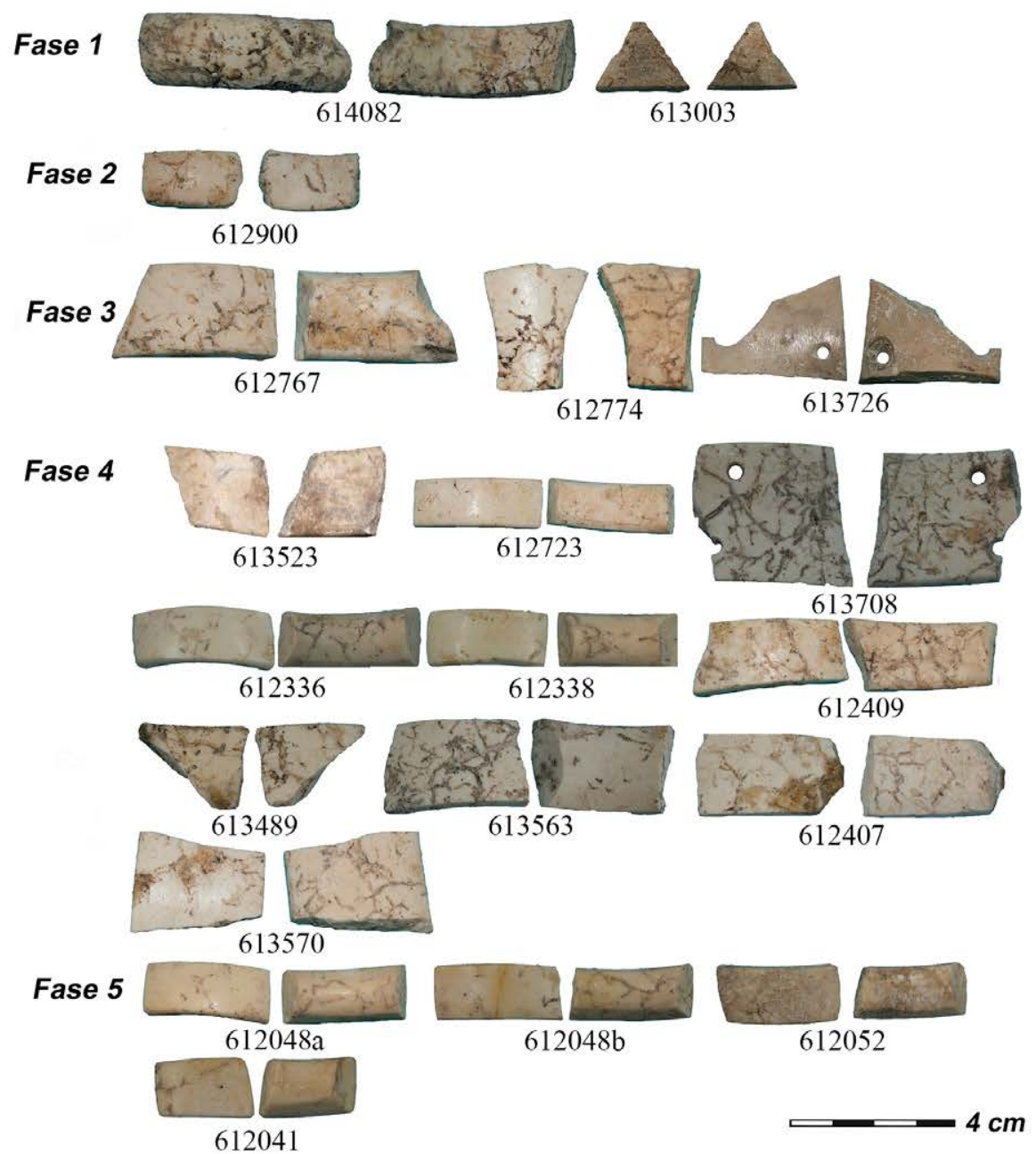

Figura 6. Elementos anulares: Neolítico Antiguo: 614082; 613003, MF94612900, 612767, 612774, 613726, $613523,612723,613708,612336,612338,612409,613489,613563,612407,613570,12048 a, 612048 b, 612052 y$ 612041.

$612774,613726,613523,612723,613708,612336,612338,612409,613489,613563$, 612407, 613570, 12048a, 612048b, 612052, 612041; Neolítico Medio: 611911, 611978, 61141a, 61141b, 69682, 611336, 611359, 611401a, 611423a, 68502a, 68502b, 65214, 611192a, 610626, 611193, 611251, 612213; 611145, 611211, 614141, 610309, 610399, 65080, 610172, 61022, 69921a, 69921b, 610104, 369958, 69891, 69669, 69668, 613241, 6978a, 69978b, 64894, 69470, 69243, 69292, 64831; Neolítico Tardío: 68629, 68934, 63744, 63702, 63734, 68278, 67616, 64588, 63619, 69177; Neolítico Final: 62538, 63552; Cobre Antiguo: 62114, 63605a). 


\section{Neolítico Medio}

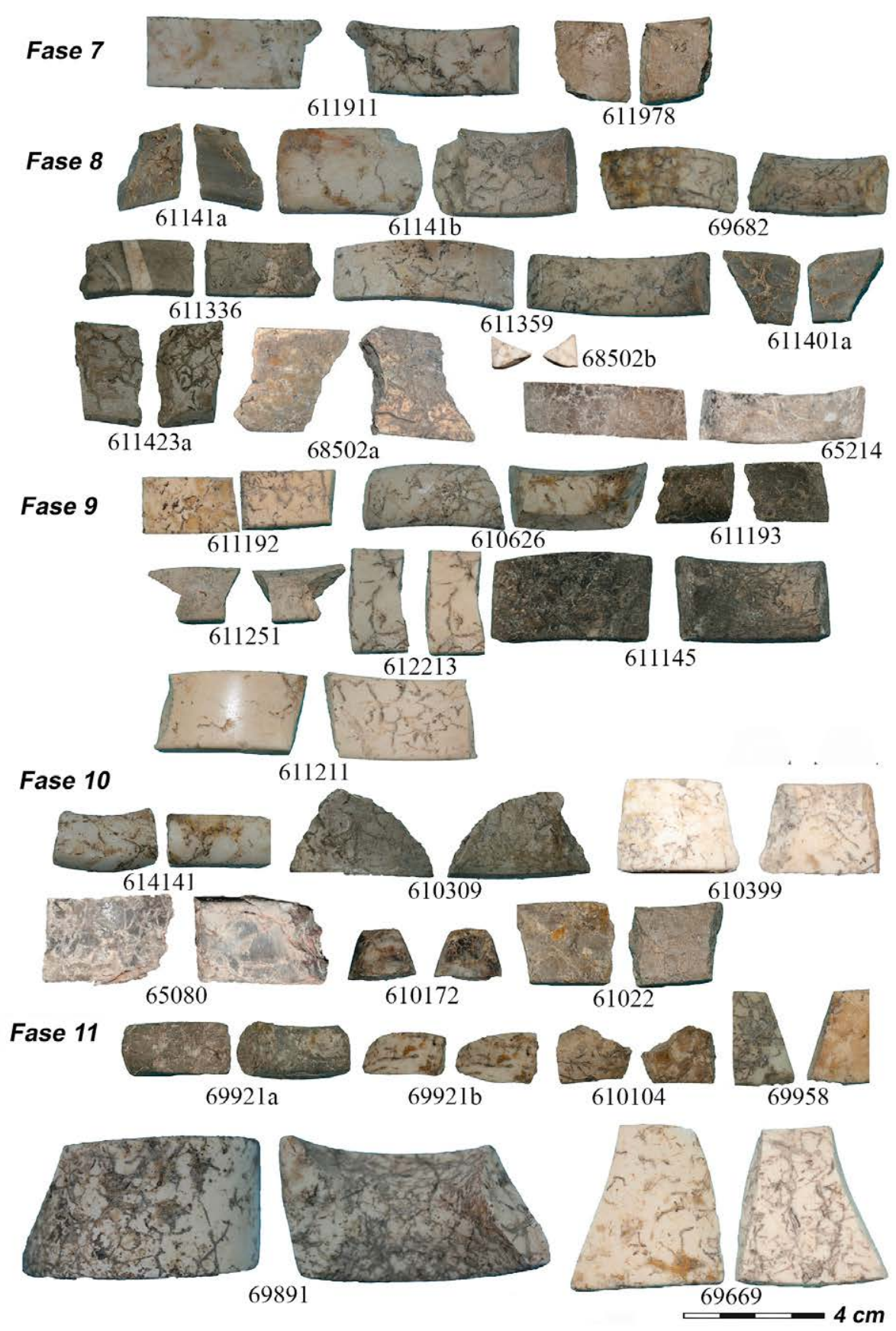

Figura 7. Elementos anulares: Neolítico Medio: 611911, 611978, 61141a, 61141b, 69682, 611336, 611359, 611401a, 611423a, 68502a, 68502b, 65214, 611192a, 93610626, 611193, 611251, 612213; 611145, 611211, 614141, 610309, 610399, 65080, 610172, 61022, 69921a, 69921b, 610104, 369958, 69891, 69669,

\section{$\underline{\text { Subgrupo } 2}$}

Los elementos del subgrupo 2 han sido obtenidos a partir de concha (un total de 13 fragmentos) y presentan un diámetro interno entre 4 y $7 \mathrm{~cm}$. (Neolítico Medio: 65152, 610842, 64934, 610188, 610012, 610248, 69829, 610141; Neolítico Tardío: 64685, 63741, 68940, 69236; Neolítico Final: 69401). 


\section{Neolítico Medio}

\section{Fase 11}

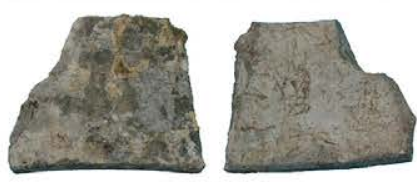

69668
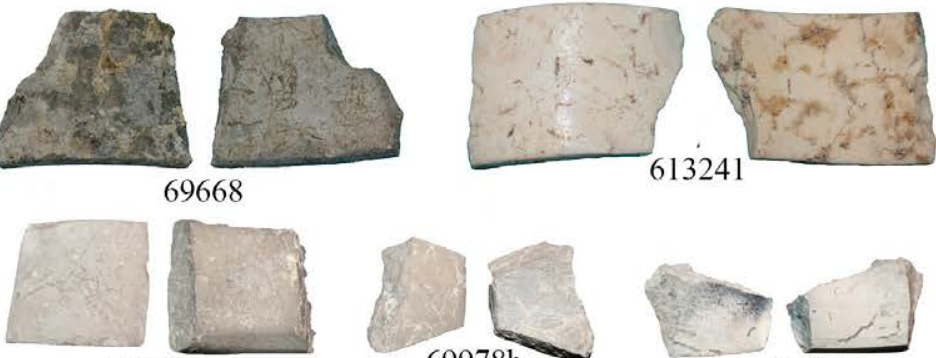

$69978 \mathrm{a}$

$69978 b$
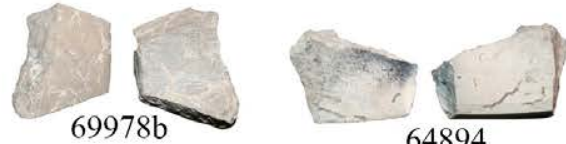

64894

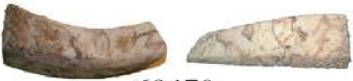

69470
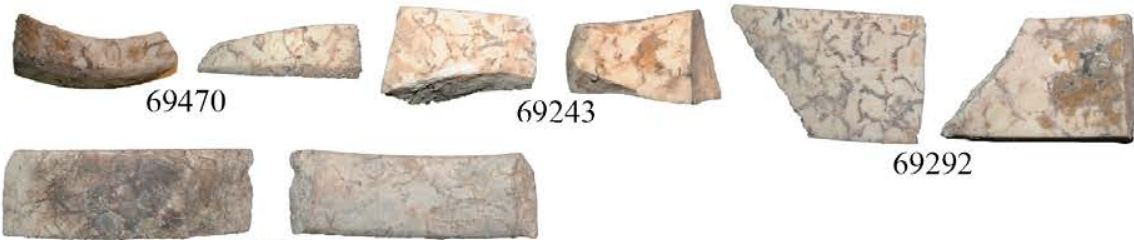

69292

64831

\section{Neolítico Tardío}

\section{Fase 12}
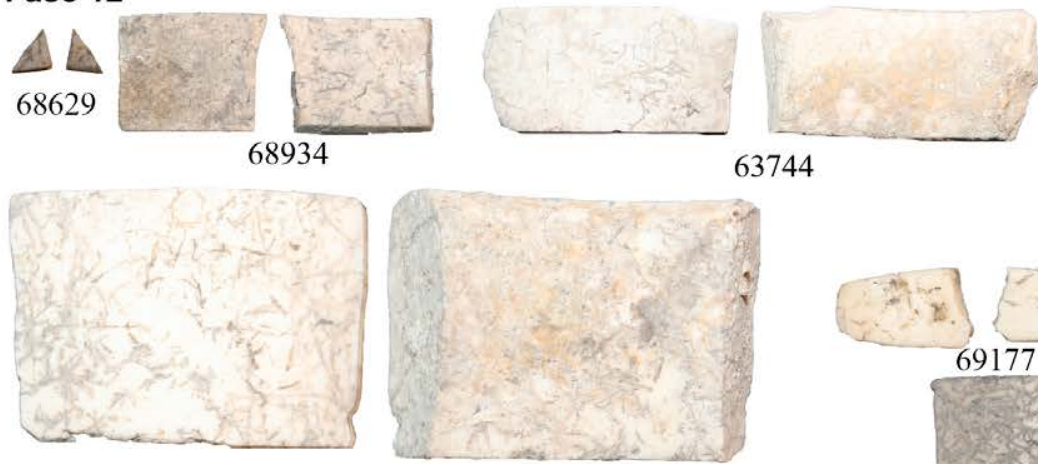

63702
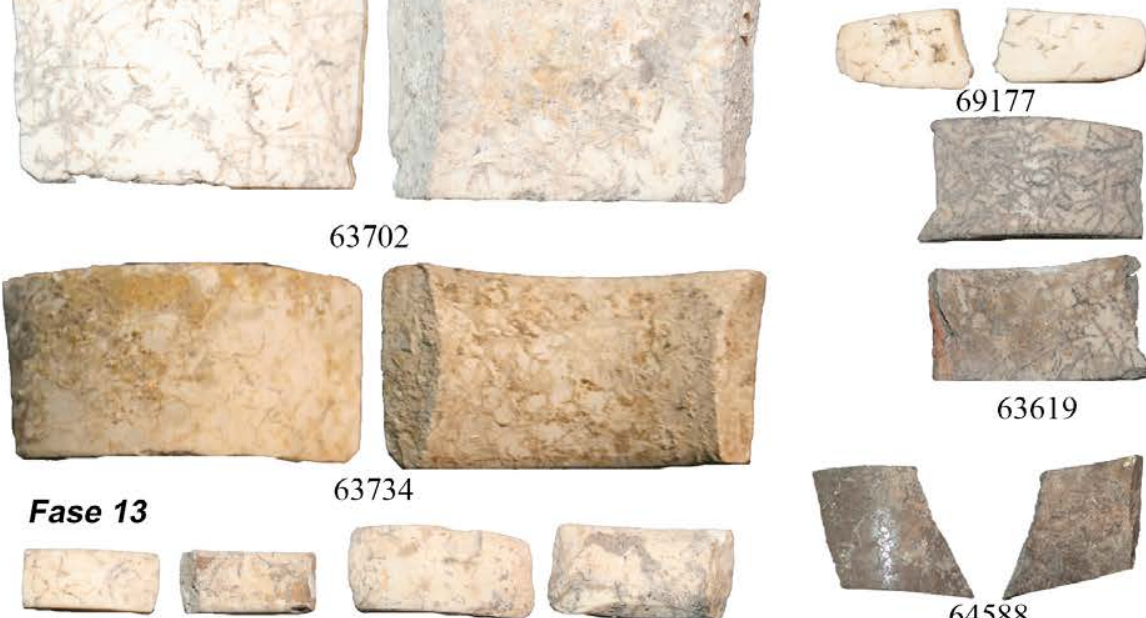

63734

68278

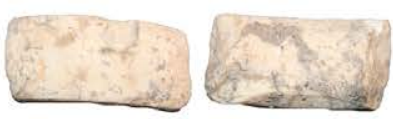

67616

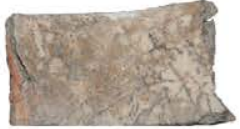

63619

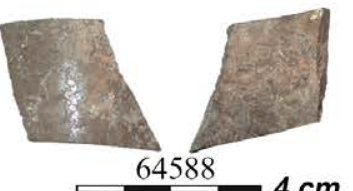

Figura 8. Elementos anulares: Neolítico Medio: 69668, 613241, 6978a, 69978b, 64894, 69470, 69243, 69292, 64831, Neolítico Tardío: 68629, 68934, 63744, 63702, 63734, 68278, 67616, 64588, 63619, 69177.

\section{Elementos cónicos (categoría IV)}

Indicamos como elementos de forma cónica algunos artefactos de sección triangular con la base plana. Corresponden a un periodo comprendido entre el Neolítico Antiguo y Tardío (Figura 10) $(612214,511569,610204,6153,65300,64857,68843$, 68953c). 


\section{CATEGORÍA III}

\section{GRUPO 2 \\ SUBGRUPO 2}

\section{Neolítico Medio}

Fase 9

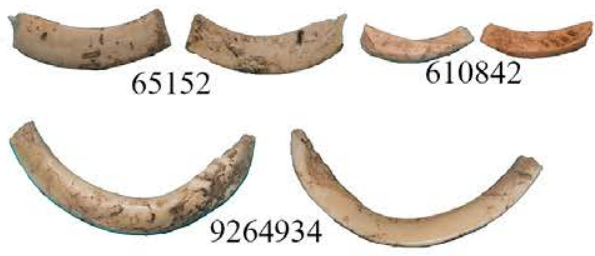

Fase 10

Fase 11
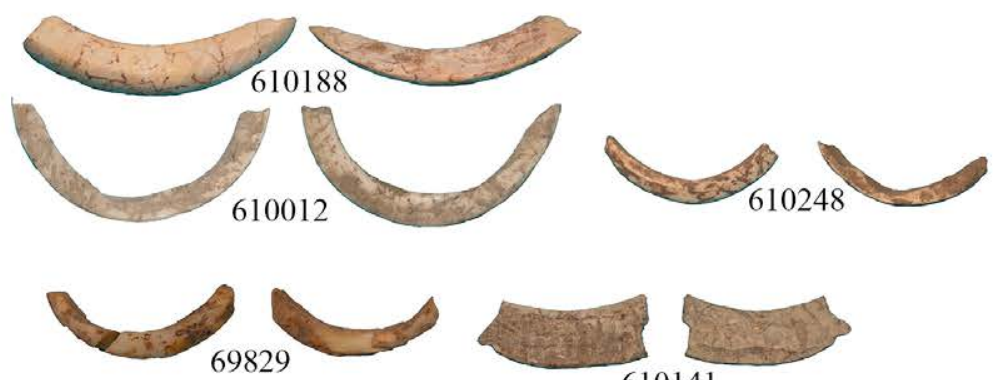

\section{Neolítico Tardío}

\section{Fase 12}

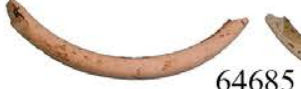

64685

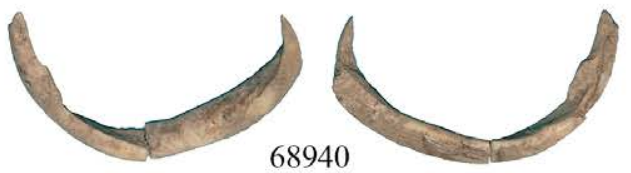

68940

\section{Fase 13}

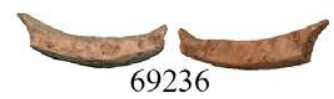

\section{Neolítico Final}

\section{Fase 15}

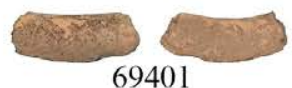

69401

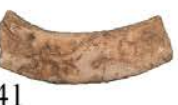

63741

Figura 9. Elementos anulares: Neolítico Medio: 65152, 610842, 64934, 610188, 610012, 610248, 69829, 610141, Neolítico Tardío: 64685, 63741, 68940 y 69236, Neolítico final: 69401.

\section{Alfileres (categoría V)}

Definimos como alfileres a tres artefactos realizados en hueso pulido, en forma de varilla, con sección cilíndrica o cuadrangular y una o las dos extremidades puntiagudas, con o sin cabeza. Los alfileres no poseen ni perforación, ni muescas, por lo que su sistema de fijación es directo. Podemos dividir los artefactos de esta categoría en dos grupos: los alfileres con cabeza fija (grupo 1) y los que tienen cabeza móvil (grupo 2) (Figura 10) (64173, 66109 y 66339). 


\section{CATEGORÍA IV}

\section{Neolítico Antiguo/Medio/Tardío}
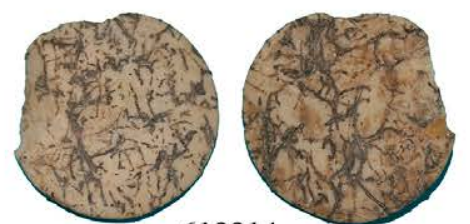

612214
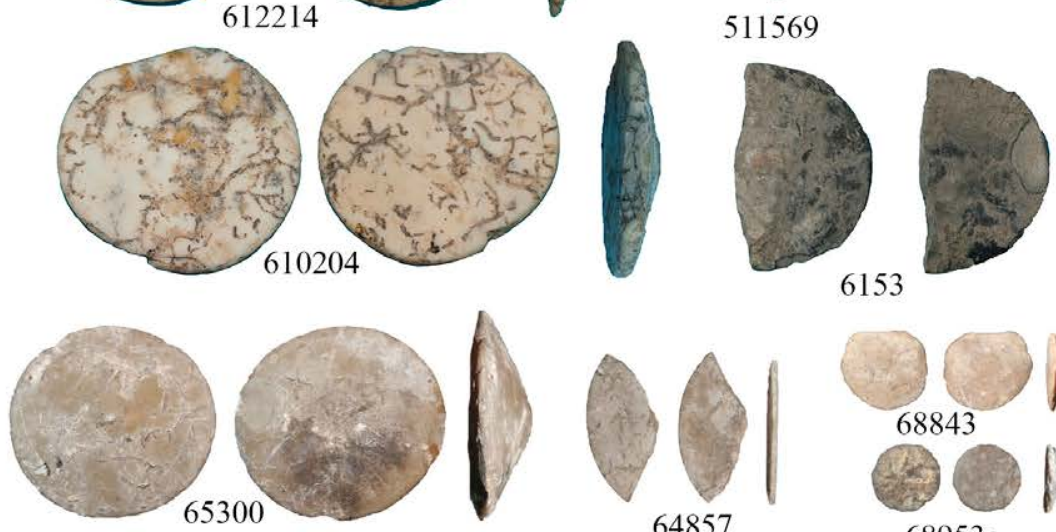

64857

6153

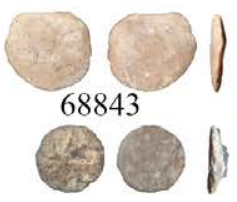

$68953 \mathrm{c}$

\section{CATEGORÍA V}

GRUPO 1

Cobre Antiguo

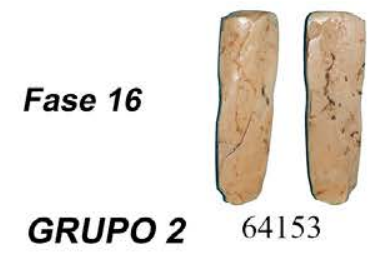

Cobre Antiguo

Fase 16

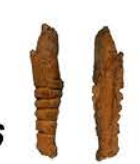

66109

\section{CATEGORÍA VI}

Neolítico Final

\section{Fase 15}

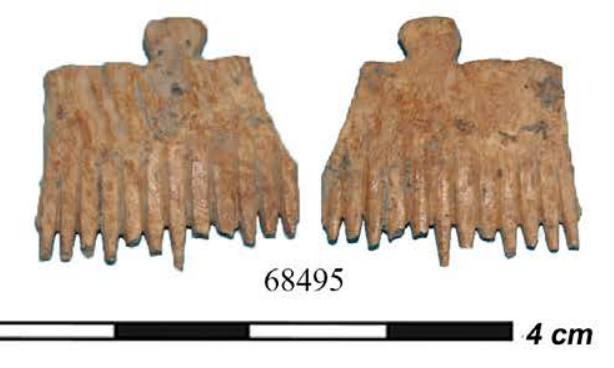

66339

$4 \mathrm{~cm}$

Figura 10. Elementos cónicos: Neolítico Antiguo/Tardío: 612214, 511569, 610204, 6153, 65300, 64857, 68843, 68953c; Alfileres: Cobre Antiguo: 64173, 66109 y 66339; Elementos dentados: Neolitico Final: 68495.

\section{Elementos dentados (categoría VI)}

Los elementos dentados ( 1 artefacto), definidos generalmente como peines, son piezas muy cuidadas que presentan en uno de los bordes una serie de dientes. (Figura 10) (68495). 
Elementos en fase de elaboración

A estos objetos tenemos que añadir dos elementos anulares (categoría III, grupo 2, subgrupo 1) $(69412,63725)$ en fase de elaboración. Mientras el primero de ellos procede de la limpieza de los bloques que precedieron a la ocupación (fase 0), el segundo, muy fragmentado, se localizó en un conjunto de fauna atribuido a los momentos inmediatamente posteriores al hiato (fase 12).

\section{Estudio tipológico de los artefactos por orden cronológico}

\section{Neolítico Antiguo Avanzado (Tabla 2)}

En la fase 0 (nivel de cimentación previa a la fase 1), se recuperaron dos colgantes de concha entera (categoría I, grupo 1), un elemento con perforación en el ápice (6150) y otro con perforación artificial en la última vuelta (614255b). Además, a esta fase, como hemos dicho, previa a la verdadera primera ocupación estable del área excavada, se puede adscribir uno de los brazaletes en fase de elaboración (69412). En niveles correspondientes a la primera fase estratigráfica se recuperaron dos elementos anulares (categoría III, grupo 2, subgrupo 1, tipo 3) (614082; 613003). En la sucesiva fase 2 se recuperaron un colgante rectangular (categoría I, grupo 2) de forma pseudorectangular de contorno irregular (613854) fragmentado en la extremidad superior donde se encuentra la perforación circular con sección cilíndrica, y dos elementos anulares (categoría III, grupo 2, subgrupo 1), uno del tipo 2 (613998) y otro del tipo 3 (612900). A la fase 3 se han adscrito una cuenta cilíndrica (categoría II, grupo 3) (612638) y tres elementos anulares (categoría III, grupo 2, subgrupo 1, tipo 3) $(612767,612774$, 613726). A la fase 4, sin mayor precisión, pertenecen dos colgantes de concha entera (categoría I grupo 1), una Columbella perforada intencionalmente en la última vuelta (612949), un colgante constituido por el exosqueleto de un gasterópodo completamente trasformado por la acción del mar (613853) y un fragmento de elemento anular (categoría III, grupo 2, subgrupo 1, tipo 3) (613523). Se han encontrado en niveles de la fase $4 \mathrm{a}$, dos elementos anulares (categoría III, grupo 2, subgrupo 1, tipo 3) (612723, 613708). Corresponden a la fase $4 \mathrm{~b}, 11$ fragmentos de elementos anulares (categoría III, grupo 2, subgrupo 1), dos del tipo $1(612402,612010)$, dos del tipo $2(612473,611990)$ y siete del tipo 3 (612336, 612338, 612409, 613489, 613563, 612407, 613570). Dentro de la fase $4 \mathrm{~b}$ procede un colgante rectangular (categoría I, grupo 2) (612579), roto en sus dos extremos y que fue obtenido de un colmillo de Sus scrofa. Presenta todavía la forma curvilínea natural de la materia prima y del agujero de sujeción se conserva solo una parte, aunque en origen tendría que presentar una forma circular y una sección cónica. En los niveles de la fase 5 se encontraron cuatro elementos anulares (categoría III, grupo 2, subgrupo 1, tipo 3) (612048a, 612048b, 612052, 612041).

\section{Neolítico Medio Inicial (Tabla 2)}

A la fase 7 corresponden dos colgantes de concha entera (categoría I, grupo 1) con perforación intencional en la última vuelta $(613406,611653)$, tres elementos anulares (categoría III, grupo 2, subgrupo 1), uno del tipo 1 (611936) y dos del tipo 3 (611911, 611978).

Se han encontrado en niveles de la fase 8 , un colgante de concha entera (categoría I, grupo 1) (611357) y un elemento anular (categoría III, grupo 1) (65226) que presenta forma ovalada, cuerpo cóncavo-convexo. Este último conserva la forma natural del hueso con el que fue manufacturado y su perímetro exterior muestra una sección plana de diferente espesor y una zona con mayor anchura de forma subrectangular con los vértices redondeados. Por su forma podemos definir este artefacto como elemento 


\begin{tabular}{|c|c|c|c|c|c|c|c|}
\hline Período & Fase & Objetos de adorno & Categoría & Grupo & Subgrupo & Tipo & Total artefactos \\
\hline \multirow{8}{*}{$\begin{array}{l}\text { Neolítico } \\
\text { Antiguo }\end{array}$} & o & 2 colgantes de concha & I & 1 & & & \multirow{8}{*}{32} \\
\hline & 1 & 2 elementos anulares & III & 2 & 1 & 3 & \\
\hline & 2 & $\begin{array}{l}1 \text { colgante rectangular } \\
1 \text { elemento anular } \\
1 \text { elemento anular } \\
\end{array}$ & $\begin{array}{l}\text { I } \\
\text { III } \\
\text { III }\end{array}$ & $\begin{array}{l}2 \\
2 \\
2 \\
\end{array}$ & $\begin{array}{l}1 \\
1\end{array}$ & $\begin{array}{l}2 \\
3 \\
\end{array}$ & \\
\hline & 3 & $\begin{array}{l}1 \text { cuenta cilíndrica } \\
3 \text { elementos anulares }\end{array}$ & $\begin{array}{l}\text { II } \\
\text { III }\end{array}$ & $\begin{array}{l}3 \\
2\end{array}$ & 1 & 3 & \\
\hline & $4 a / b$ & \begin{tabular}{|l|}
2 colgantes de concha \\
1 elemento anular \\
\end{tabular} & III & $\begin{array}{l}1 \\
2 \\
\end{array}$ & 1 & 3 & \\
\hline & $4 a$ & 2 elementos anulares & III & 2 & 1 & 3 & \\
\hline & $4 b$ & $\begin{array}{l}1 \text { colgante rectangular } \\
2 \text { elementos anulares } \\
2 \text { elementos anulares } \\
7 \text { elementos anulares }\end{array}$ & $\begin{array}{l}\text { I } \\
\text { III } \\
\text { III } \\
\text { III }\end{array}$ & $\begin{array}{l}2 \\
2 \\
2 \\
2\end{array}$ & $\begin{array}{l}1 \\
1 \\
1\end{array}$ & $\begin{array}{l}1 \\
2 \\
3\end{array}$ & \\
\hline & 5 & 4 elementos anulares & III & 2 & 1 & 3 & \\
\hline- & & 8 elementos cónicos & IV & & & & 8 \\
\hline \multirow{8}{*}{$\begin{array}{l}\text { Neolítico } \\
\text { Medio }\end{array}$} & 7 & $\begin{array}{l}2 \text { colgantes de concha } \\
1 \text { elemento anular } \\
2 \text { elementos anulares }\end{array}$ & $\begin{array}{l}\text { I } \\
\text { III } \\
\text { III }\end{array}$ & $\begin{array}{l}1 \\
2 \\
2\end{array}$ & $\begin{array}{l}1 \\
1\end{array}$ & $\begin{array}{l}1 \\
3\end{array}$ & \multirow{8}{*}{78} \\
\hline & 8 & $\begin{array}{l}1 \text { colgante de concha } \\
1 \text { elemento anular } \\
2 \text { elemento anular } \\
10 \text { elementos anulares }\end{array}$ & $\begin{array}{l}\text { I } \\
\text { III } \\
\text { III } \\
\text { III }\end{array}$ & $\begin{array}{l}1 \\
1 \\
2 \\
2\end{array}$ & $\begin{array}{l}1 \\
1\end{array}$ & $\begin{array}{l}1 \\
3\end{array}$ & \\
\hline & 9 & $\begin{array}{l}3 \text { colgantes de concha } \\
1 \text { cuenta discoidal } \\
2 \text { elemento anular } \\
1 \text { elemento anular } \\
7 \text { elementos anulares } \\
3 \text { elementos anulares } \\
\end{array}$ & $\begin{array}{l}\text { I } \\
\text { II } \\
\text { III } \\
\text { III } \\
\text { III } \\
\text { IIII }\end{array}$ & $\begin{array}{l}1 \\
2 \\
2 \\
2 \\
2 \\
2 \\
\end{array}$ & $\begin{array}{l}1 \\
1 \\
1 \\
2 \\
\end{array}$ & $\begin{array}{l}1 \\
2 \\
3\end{array}$ & \\
\hline & $10 a / b$ & 1 elemento anular & III & 2 & 1 & 3 & \\
\hline & $10 \mathrm{a}$ & $\begin{array}{l}1 \text { cuenta discoidal } \\
1 \text { elemento anular } \\
1 \text { elemento anular } \\
3 \text { elemento anular } \\
\end{array}$ & $\begin{array}{l}\text { II } \\
\text { III } \\
\text { III } \\
\text { III }\end{array}$ & $\begin{array}{l}2 \\
2 \\
2 \\
2 \\
\end{array}$ & $\begin{array}{l}1 \\
1 \\
1\end{array}$ & $\begin{array}{l}1 \\
2 \\
3\end{array}$ & \\
\hline & $10 \mathrm{~b}$ & \begin{tabular}{|l}
1 elemento anular \\
1 elemento anular \\
2 elementos anulares
\end{tabular} & $\begin{array}{l}\text { III } \\
\text { III } \\
\text { III }\end{array}$ & $\begin{array}{l}2 \\
2 \\
2\end{array}$ & $\begin{array}{l}1 \\
2 \\
1\end{array}$ & $\begin{array}{l}1 \\
3\end{array}$ & \\
\hline & $11 \mathrm{a}$ & $\begin{array}{l}2 \text { colgantes de lágrimas } \\
1 \text { cuenta cilíndrica } \\
3 \text { elementos anulares } \\
11 \text { elementos anulares } \\
4 \text { elementos anulares } \\
\end{array}$ & $\begin{array}{l}\text { I } \\
\text { II } \\
\text { III } \\
\text { III } \\
\text { III }\end{array}$ & $\begin{array}{l}3 \\
3 \\
2 \\
2 \\
2\end{array}$ & $\begin{array}{l}1 \\
1 \\
2\end{array}$ & $\begin{array}{l}1 \\
3\end{array}$ & \\
\hline & $11 b$ & $\begin{array}{l}1 \text { colgante rectangular } \\
3 \text { colgantes de lágrima } \\
2 \text { elementos anulares } \\
4 \text { elementos anulares }\end{array}$ & $\begin{array}{l}\text { I } \\
\text { I } \\
\text { III } \\
\text { III }\end{array}$ & $\begin{array}{l}2 \\
3 \\
2 \\
2\end{array}$ & $\begin{array}{l}1 \\
1\end{array}$ & $\begin{array}{l}1 \\
3\end{array}$ & \\
\hline \multirow{3}{*}{$\begin{array}{l}\text { Neolítico } \\
\text { Tardío }\end{array}$} & 12 & $\begin{array}{l}2 \text { cuentas discoidales } \\
3 \text { elementos anulares } \\
4 \text { elementos anulares } \\
5 \text { elementos anulares } \\
2 \text { colgantes de lágrima }\end{array}$ & $\begin{array}{l}\text { II } \\
\text { III } \\
\text { III } \\
\text { III } \\
\text { I }\end{array}$ & $\begin{array}{l}2 \\
2 \\
2 \\
2 \\
3\end{array}$ & $\begin{array}{l}2 \\
1 \\
1\end{array}$ & $\begin{array}{l}1 \\
3\end{array}$ & \multirow{3}{*}{27} \\
\hline & 13 & $\begin{array}{l}1 \text { colgante rectangular } \\
1 \text { cuenta discoidal } \\
1 \text { elemento anular } \\
1 \text { elemento anular } \\
5 \text { elemento anular }\end{array}$ & $\begin{array}{l}\text { I } \\
\text { II } \\
\text { III } \\
\text { III } \\
\text { III }\end{array}$ & $\begin{array}{l}2 \\
2 \\
2 \\
2 \\
2\end{array}$ & $\begin{array}{l}2 \\
1 \\
1\end{array}$ & $\begin{array}{l}1 \\
3\end{array}$ & \\
\hline & 14 & $\begin{array}{l}1 \text { colgante rectangular } \\
1 \text { cuenta discoidal }\end{array}$ & I & $\begin{array}{l}2 \\
2\end{array}$ & & & \\
\hline
\end{tabular}




\begin{tabular}{|c|c|c|c|c|c|c|c|}
\hline Período & Fase & Objetos de adorno & Categoría & Grupo & Subgrupo & Tipo & Total artefactos \\
\hline \multirow[t]{2}{*}{$\begin{array}{l}\text { Neolítico } \\
\text { Final }\end{array}$} & 15 & $\begin{array}{l}1 \text { cuenta de concha } \\
2 \text { cuentas discoidales } \\
1 \text { elemento anular } \\
1 \text { peine }\end{array}$ & $\begin{array}{l}\text { II } \\
\text { II } \\
\text { III } \\
\text { V }\end{array}$ & $\begin{array}{l}1 \\
2 \\
2\end{array}$ & 2 & & \multirow[t]{2}{*}{8} \\
\hline & $16 \mathrm{a}$ & $\begin{array}{l}1 \text { cuenta de concha } \\
2 \text { elemento anular }\end{array}$ & $\begin{array}{l}\text { II } \\
\text { II }\end{array}$ & $\begin{array}{l}1 \\
1\end{array}$ & 2 & 3 & \\
\hline \multirow[t]{2}{*}{$\begin{array}{l}\text { Cobre } \\
\text { Antiguo }\end{array}$} & $16 \mathrm{~b}$ & $\begin{array}{l}1 \text { alfileres } \\
2 \text { alfileres } \\
2 \text { elemento anular }\end{array}$ & $\begin{array}{l}\mathrm{V} \\
\mathrm{V} \\
\mathrm{II}\end{array}$ & $\begin{array}{l}1 \\
2 \\
1 \\
\end{array}$ & 2 & 3 & \multirow[t]{2}{*}{6} \\
\hline & 17 & 1 cuenta bitroncocónica & II & 4 & & & \\
\hline Cobre Pleno & 18 & 1 cuenta bitroncocónica & II & 4 & & & 1 \\
\hline \multicolumn{7}{|c|}{ *2 elementos anulares en fase de elaboración (cronología desconocida) } & $160+2^{*}=162$ \\
\hline
\end{tabular}

Tabla 2. Clasificación por orden cronológico de los objetos de adorno personal de Los Castillejos en la Peña de los Gitanos en Montefrío (Granada).

anular de tipo abultado (Pascual, 1998, p. 154). De la misma fase 8 son nueve elementos anulares (categoría III, grupo 2, subgrupo 1), dos del tipo 1 (611401b, 65034) y siete del tipo 3 (61141a, 61141b, 69682, 611336, 611359, 611401a, 611423a). En niveles de la fase 9 se hallaron tres colgantes de concha entera (categoría I grupo 1) (611283, $614165,6112829)$, uno de los cuales está completamente modificado por la acción del mar, una cuenta discoidal (categoría II, grupo 2) (611032) en material lítico, con una cara plana y la otra plano-cóncava y con agujero central circular con sección cilíndrica. Corresponden a esta misma fase, 13 elementos anulares (categoría III, grupo 2 , subgrupo 1), dos del tipo $1(611270,65123)$, uno del tipo $2(613338 b)$ y 10 del tipo 3 (611192a, 610626, 611193, 611251, 612213, 611145, 611211, 68502a, 68502b, 65214), además de tres elementos anulares de la categoría III, grupo 2 y subgrupo 2 (65152, $610842,64934)$. También a la fase estratigráfica 10 (sin mayor precisión) se adscribe un elemento anular (categoría III, grupo 2, subgrupo 1, tipo 3) (61414).

A la fase 10a se ha adscrito un pequeño disco (categoría II, grupo 2) incompleto (610180a) en concha, con el cuerpo muy aplanado y el agujero central de forma circular con sección cilíndrica, y cinco elementos anulares (categoría III, grupo 2, subgrupo 1), uno del tipo 1 (65081), uno del tipo 2 (610233) y tres del tipo $3(610309,610399$, 65080). De niveles de la fase 10b proceden cuatro elementos anulares (categoría III, grupo 2), uno del subgrupo 1 tipo 1 (64924), uno del subgrupo 2 (610188), y dos del subgrupo 1, tipo 3 (610172, M61022). En particular el artefacto 64924 presenta una perforación en una de las extremidades de forma circular y sección bicónica.

Pertenecen a la fase 11a, dos colgantes de lágrima (categoría I, grupo 3) en material lítico $(610683,69748)$, rotos en el margen superior quedando incompletos en el orificio de perforación con sección bicónica. También en niveles de la misma fase 11a se han recuperado una cuenta cilíndrica (categoría II, grupo 3) (6106829) y 18 elementos anulares (categoría III, grupo 2), tres del subgrupo 1 y tipo $1(69695,69734,610440)$ y 11 del subgrupo 1 y del tipo 3 (69921a, 69921b, 610104, 369958, 69891, 69669, 69668, 613241, 6978a, 69978b, 64894) y cuatro del subgrupo 2 (610012, 610248, 69829, 610141). A niveles de la fase 11b se adscriben un colgante rectangular (categoría I, grupo 2) (69508) que presenta los márgenes rectos con las esquinas redondeadas y una perforación ubicada en la parte superior del colgante ligeramente escorada a la izquierda con sección cilíndrica. A la misma fase estratigráfica 11b, pertenecen tres colgantes de lágrima (categoría I, grupo 3) $(69678,69308,69544)$ en piedra. El primer artefacto ofrece en el margen superior una perforación circular con sección bicónica entera y está fracturado en su margen inferior, mientras que los otros dos colgantes han perdido la extremidad superior, quedando incompleto el orificio de perforación que en uno de los objetos presenta la sección bicónica y en la otra cilíndrica. Por último 
debemos citar seis elementos anulares de la fase 11b (2 de la categoría III, grupo 2, subgrupo1, tipo 1, 69576, 69639; y 2 de la categoría III, grupo 2, subgrupo 1, tipo 3, 69470, 69243, 69292, 64831).

Además de todos estos materiales localizados en fases atribuidas al Neolítico Medio Inicial, otra serie de objetos, cuya adscripción estratigráfica es más insegura, aunque siempre anteriores a la fase 13 y casi todos del Neolítico Medio, deben ser citados en este punto. Nos referimos a ocho elementos cónicos (categoría IV) $(612214,611569,610204,6153$, $65300,64857,68843,68953$ c) manufacturados en piedra, cinco enteros y tres incompletos.

\section{$\underline{\text { Neolítico Tardío (Tabla 2) }}$}

En niveles correspondientes a la fase estratigráfica 12 se hallaron dos colgantes de lágrima (categoría I, grupo 3) en material lítico (68953-2, 68977), que están fracturados en la zona de la perforación (sección cilíndrica), y dos cuentas discoidales (categoría II, grupo 2) en piedra, la primera con perforación central de forma circular y sección cilíndrica (68953a) y la segunda con un pequeño orificio central de forma circular y sección troncocónica (69070). Pertenecen a la misma fase 12 elementos anulares, tres de la categoría III, grupo 2, subgrupo 2 (64685, 63741, 68940), cuatro de la categoría III, grupo 2 , subgrupo 1 , tipo $1(63727,64983,68466 a, 68466 b)$ y cinco de la categoría III, grupo 2, subgrupo 1, tipo 3 (68629, 68934, 63744, 63702, 63734). En los artefactos 68466a y b, resulta notable la presencia de perforaciones circulares con sección bicónica y en particular la presencia de un orificio en fase de elaboración. A la fase estratigráfica 13 corresponde un colgante rectangular en hueso (categoría I, grupo 2) (67595), roto en su margen inferior. En su parte superior presenta un agujero de forma circular y sección cilíndrica. También a esta fase se adscriben siete elementos anulares (categoría III, grupo 2), uno del subgrupo 2 (69236), uno de subgrupo 1 y tipo 1 (68543) y cinco del subgrupo 1 y tipo $3(68278,67616,64588,63619,69177)$, además de una cuenta discoidal (categoría II, grupo 2) (67948a), en material lítico y con perforación central de sección cilíndrica. A los niveles más recientes del Neolítico Tardío, fase estratigráfica 14, pertenece un colgante rectangular (categoría 1, grupo 2) (68377) con doble perforación circular, una de ellas completa (de sección cónica) y otra incompleta (de sección cilíndrica). Este objeto conserva todavía en el reverso la oquedad natural del hueso. En la misma fase se ha recuperado una cuenta discoidal (categoría II, grupo 2) (63682), en material lítico que presenta perforación central con sección cilíndrica.

\section{Neolítico final (Tabla 2)}

Pertenecen a la fase estratigráfica 15 una cuenta de concha entera (categoría II, grupo 1) (68518b), dos cuentas discoidales (categoría II, grupo 2) $(68517,68502$ c), una de las dos con el borde irregular, un elemento anular (categoría III, grupo 2, subgrupo 2) (69401) y también el único peine (categoría VI) del conjunto estudiado (68495), de forma subrectangular, con un apéndice trapezoidal y 12 pequeños dientes incompletos. A la fase estratigráfica 16a se ha adscrito una cuenta de concha entera (categoría II, grupo 1) (67545). En la misma fase se han recuperado también dos elementos anulares (categoría III, grupo2, subgrupo 1 tipo 3) $(62538,63552)$, probablemente intrusivos si tenemos en cuenta las profundas alteraciones documentadas en el área en que se hallaron (sector F) provocadas por la continua realización de fosas piriformes desde (comúnmente llamadas silos) que afectaron, sobre todo, a los niveles del Neolítico Tardío.

\section{Cobre Antiguo (Tabla 2)}

Corresponden al Cobre Antiguo, fase estratigráfica 16b, tres cabezas de alfileres (categoría V). Una de ellas ha sido incluida en el grupo 1 (64173). Se trata de una 
espátula subrectangular de la que se conserva sólo la parte superior, la cabeza subrectangular, y presenta la cabeza aplanada y sin decoración. Otras dos se adscriben al grupo 2, con cabezas decoradas (alfileres con cabeza móvil segmentada o acanalada) con acanaladuras suaves paralelas y concéntricas (66109) y con acanaladuras más profundas y una decoración en $V$ en el borde (66339). Presentan el extremo proximal afinado para poderlos fijar con mayor facilidad al cuerpo del alfiler (Pascual, 1998). En la fase 16b se han encontrado también dos elementos anulares (categoría III, grupo 2, subgrupo 1 tipo 3) $(62144,63605 a)$ recuperados en el mismo sector $F$, cuyas alteraciones estratigráficas hemos referido para la fase anterior. De hecho, en ninguno de los otros sectores de la excavación se localizan adornos anulares en piedra posteriores al Neolítico Tardío.

A los niveles de la fase estratigráfica 17 pertenece una cuenta bitroncocónica (categoría II, grupo 4) (66320) en piedra.

$\underline{\text { Cobre Pleno (Tabla 2) }}$

Corresponde a la fase 18 del Cobre Pleno, una pequeña cuenta bitroncocónica (categoría II, grupo 4) (62894) en piedra.

\section{La materia prima}

En lo que respecta al estudio de la materia prima (Figura 11), el material malacológico constituye el 16,67\% de la muestra. Se trata de conchas de origen marino: gasterópodos, bivalvos y escafópodos. Hemos documentado 10 gasterópodos perforados que hemos interpretado como colgantes en concha, 13 fragmentos de bivalvos definidos como elementos anulares (categoría III, grupo 2, subgrupo 2), dos valvas trabajadas en forma discoidal y dos porciones de escafópodos. Las especies identificadas son frecuentes en las aguas templadas del Mediterráneo. Entre los gasterópodos documentados, tanto el Conus meditarraneus (un ejemplar) y la Columbella rústica (seis elementos) son especies que viven en el litoral. No ha sido posible identificar la especie de dos de los gasteropodos por el fuerte grado de trasformación natural. Los bivalvos son probablemente de la especie Glycymeris bimaculata y las dos porciones de escafópodos pertenecen a un Dentalium y a un Antalis. Identificar el tipo de materia prima de las pequeñas cuentas discoidales ha sido difícil por el alto grado de trasformación y el reducido tamaño de los artefactos. Estos factores implican además que no siempre sea segura la distinción entre las cuentas en concha, caliza y huevo de avestruz. En cualquier caso, el análisis microscópico ha permitido identificar los soportes de muchas de ellas como conchas de moluscos trabajadas, en concreto, bivalvos.

El uso del hueso para la manufactura de los objetos de adorno estudiados se limita al 5,56\% de los artefactos. Están manufacturados utilizando huesos largos de animales de talla mediana y pequeña (colgantes, cuentas y alfileres) y sobre porciones de costillas de bóvidos hendidas (colgante subrectangular y elementos dentados). Un solo elemento parece haber sido manufacturado explotando un colmillo de Sus scrofa (colgante rectangular 612579).

La presencia de marfil está atestiguada para un único objeto de adorno, un colgante subrectangular (69508) con gran alteración térmica. Actualmente estamos realizando un estudio espectroscópico sobre los materiales ebúrneos de la prehistoria reciente del sudeste de España para determinar el tipo de marfil utilizado, teniendo en cuenta los resultados previos obtenidos para estos materiales (Schuhmacher, 2011; Schuhmacher, Cardoso y Banerjee, 2009).

Las piedras sobre las que están manufacturados los objetos de adorno analizados (76,54\%), colgantes discoidales, cuentas ovales, elementos anulares (categoría III, grupo 2, subgrupo 1) y elementos cónicos, las podemos incluir en dos grupos: el primero 


\section{La materia prima}

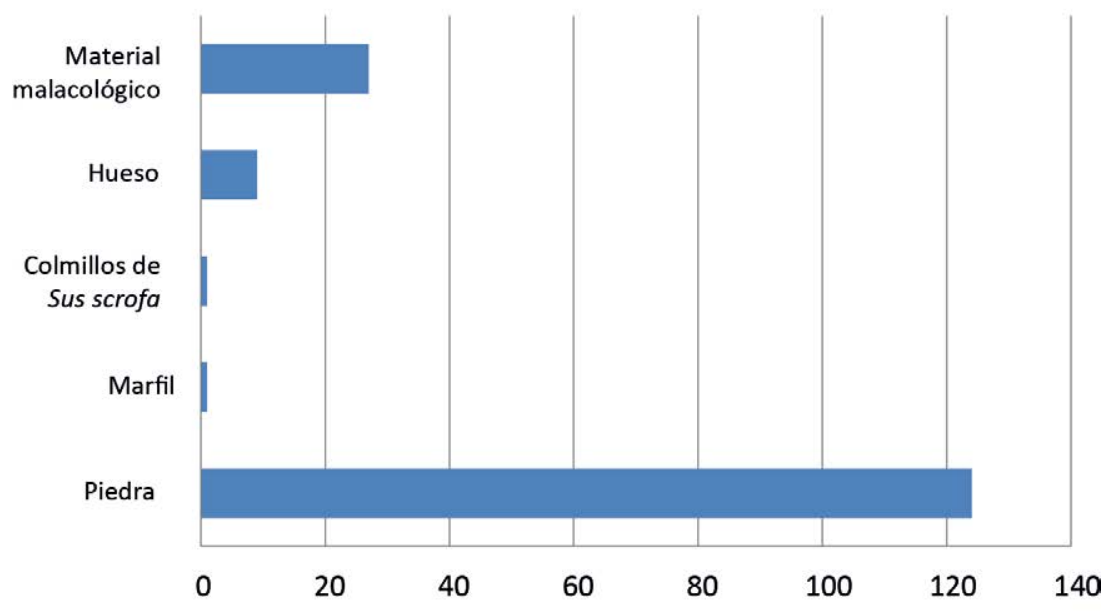

Material en piedra

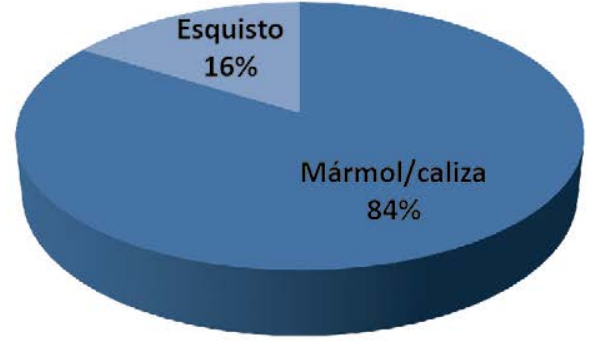

Figura 11. Los materiales utilizados en la manufacturas de los objetos de adorno de Los Castillejos en la Peña de los Gitanos en Montefrío (Granada).

caliza/mármol (104 elementos) y el segundo piedra esquistosa (pizarra) (20 elementos), siguiendo la metodología de identificación para los objetos de adorno propuesta por J.L. Pascual (Pascual, 1998, p. 158).

\section{Estudio tecnológico}

En la manufactura de los colgantes de concha entera, se ha podido constatar que el exosqueleto del molusco ha sido aprovechado en su estado original. La única acción antrópica ha sido, de hecho, la perforación ejecutada por medio de técnicas diferentes. El Conus mediterraneus fue perforado mediante la eliminación del ápice. En el caso de los colgantes obtenidos de la especie Columbella rustica vemos que en los artefactos más antiguos (Neolítico Antiguo) los agujeros de suspensión fueron realizados con las técnicas de la presión o percusión, mientras en los más recientes (Neolítico Medio) está claro el uso de la técnica de la abrasión por la presencia de estrías en el área alrededor del orificio. Entre los elementos en concha aquéllos con mayor grado de trasformación respecto a su forma original son las cuentas discoidales y los elementos anulares en Glycymeris. La manufactura de las cuentas discoidales es un proceso complejo realizado en diferentes fases: recorte de la valva, desgaste con la percusión directa con una pequeña piedra abrasiva en todo el borde hasta que se obtenga una forma poligonal, regularización de las caras y su ampliación con la técnica de la abrasión, perforación de la parte interna con el uso de un taladro mecánico, calibrado y regularización del objeto con la técnica de la abrasión para determinar un contorno perfectamente circular (Pau, 2016). En los artefactos analizados se pueden observar las huellas de las fases finales de ejecución en 
la superficie. Los elementos anulares en Glycymeris se manufacturaron con abrasión continuada de la valva en su parte superior o combinando diferentes técnicas (percusión, presión y abrasión) (Maicas, 2007, p. 167). Los elementos estudiados presentan un considerable grado de fracturación $y$, de hecho, ningún ejemplar se conserva entero. A excepción de dos casos, los elementos presentan la superficie regularizada con las técnicas de abrasión y pulido, borrando o haciendo más tenue la presencia en los bordes inferiores de los dientes de la charnela, por lo que la ondulación natural de la concha se puede observar sólo en un caso. Las cuentas en concha obtenidas con escafópodos fueron utilizadas en la prehistoria desde el Magdaleniense (Maicas, 2007, p. 180) al presentarse huecas de forma natural. En nuestro caso las piezas analizadas presentan un escaso grado de elaboración y la única alteración ha sido la eliminación de los extremos y la regularización de los bordes, aunque el mal estado de conservación de uno de estos dos artefactos (roto en un extremo) no nos ha permitido examinarlo en su totalidad.

En la cuenta cilíndrica obtenida de un hueso largo, la diáfisis fue seccionada transversalmente en ambos extremos con la técnica del aserrado o del tallado utilizando un instrumento en sílex, como se ha comprobado en otros contextos (Pascual, 1998, p. 119). Consecuentemente la superficie fue regularizada con la abrasión y el pulido como se puede constatar observando las finas estrías en los bordes de la cuenta. El anillo colgante en hueso (categoría III, grupo 1) y los colgantes rectangulares $(67595,68377)$ seguramente proceden de un hueso largo de un gran rumiante. Según J.L. Pascual Benito (1998, p. 152) este grupo de objetos se obtenía eliminando una de las epífisis. El grado de facetado de estos artefactos es total y fue conseguido con la técnica de la abrasión (aunque algunos ejemplares conserven todavía la oquedad del hueso). Seguidamente todos los artefactos fueron pulidos. En los elementos rectangulares las perforaciones fueron realizadas desde las dos caras y en un caso la perforación fue regularizada. La presencia de estrías concéntricas en los bordes internos del orificio testimonia el uso de un taladro. Para poder suspender el elemento anular el hueso fue cortado y como fase final se regularizó la pieza. Los elementos manufacturados sobre porciones de costillas de bóvidos hendidas se realizaron recortando simplemente el hueso (colgante subrectangular, 613854) o, en el caso de los elementos dentados, recortando el hueso y configurando el cuerpo y el apéndice trapezoidal con la técnica de la abrasión como se puede constatar por la contigüidad de la estrías. Por último se procedía a la realización de los dientes en el extremo opuesto al apéndice con la técnica del tallado bifacial, a partir de incisiones largas y profundas que continúan hasta el interior del cuerpo, no terminando en el espacio interdental (Altamirano, 2014, p. 31; Maicas, 2007, p. 156). Los alfileres se realizaron trabajando diáfisis de animales. La cabeza móvil, en particular, se realizó trabajando la diáfisis de un animal de pequeña talla. El artefacto sin decoración presenta la superficie facetada (abrasión y pulido muy fino) mientras que los otros dos objetos conservan en una cara todavía visible la concavidad del canal medular del hueso. Para la manufactura de las cabezas se utilizaron probablemente varias técnicas como el raspado transversal y el tallado con instrumentos de sílex.

La alteración térmica del colgante subrectangular en marfil ha dificultado su estudio traceológico. Se han definido sólo estrías finas de la fase de regularización, visibles en el extremo superior mejor conservado.

El colgante subrectangular en colmillo de Sus scrofa se elaboró cortando longitudinalmente el soporte y obteniendo una pieza de tamaño más reducido. Consecuentemente, se regularizó con las técnicas de la abrasión y del pulido la superficie interna del colmillo (Figura 12A), como lo indica la presencia de finas estrías, aunque no en manera uniforme, quedando algunas áreas mejor refinadas con respecto a otras (Figura 12A). La parte externa del artefacto conserva la superficie al natural. En el extremo superior se realizó una perforación unipolar con el uso de un taladro, como demuestra la sección de la perforación y las estrías concéntricas en su interior. 

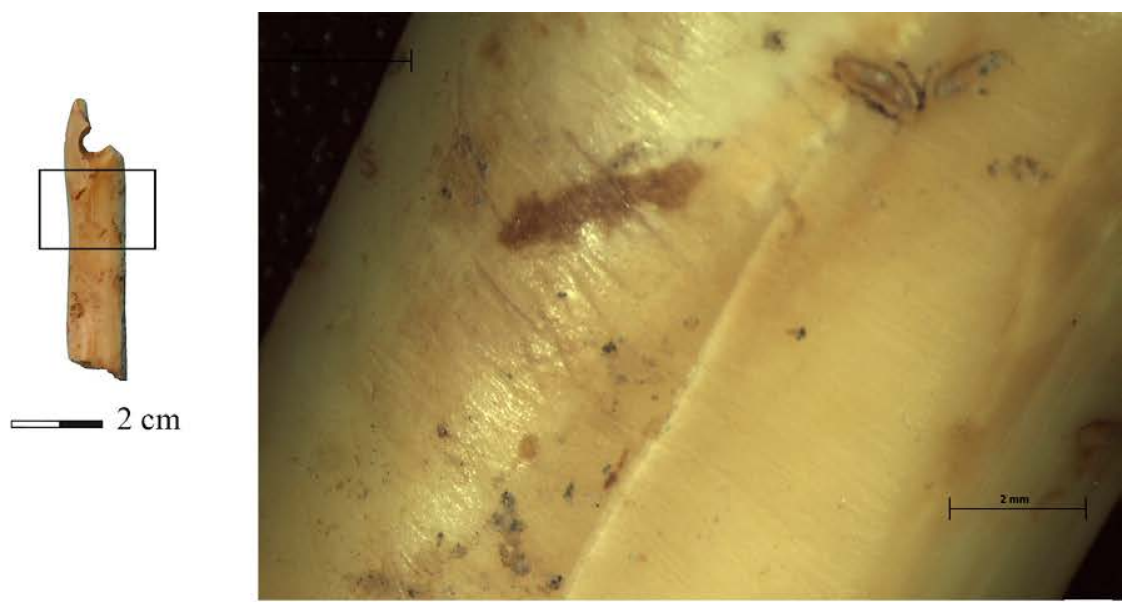

A
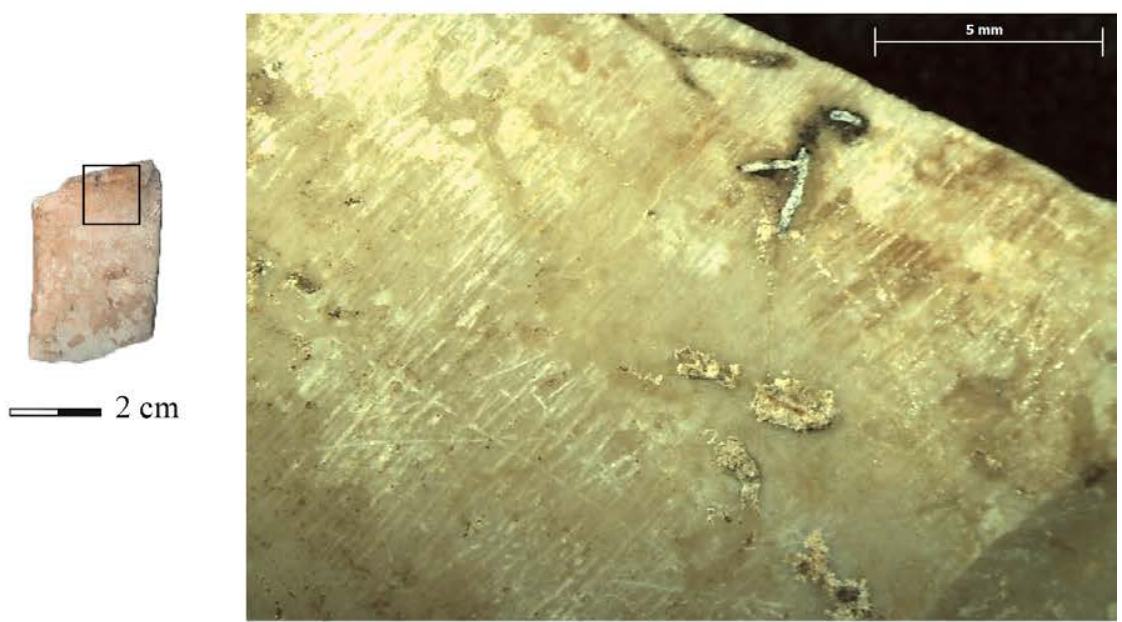

B
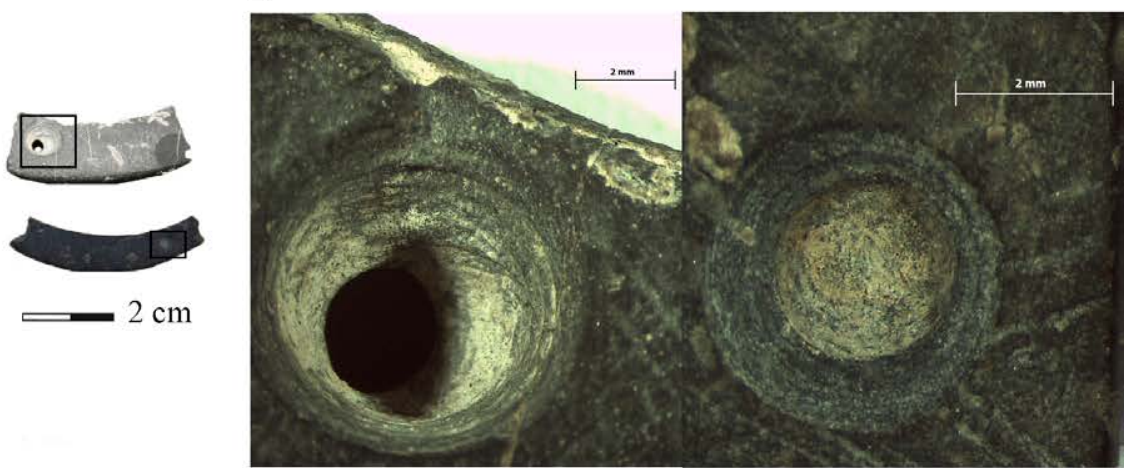

C

Figura 12. Trazas tecnológicas A) en el colgante rectangular (612579); B) en el fragmento de elemento anular (grupo 2, subgrupo 1, tipo 3) (62438); C) en los elementos anulares (68466a, 64924) (grupo 2, subgrupo 1, tipo 1).

En los colgantes de lágrima, en las cuentas discoidales, cilíndricas y bitroncocónicas, en los elementos cónicos y en los elementos anulares en piedra se puede observar un facetado total. Además son visibles las estrías producidas por la abrasión (Figura 12B), aunque algunos artefactos presentan concreciones y alteraciones, y en las superficies se distinguen vermiculaciones provocadas por la acción de las raíces de las plantas. La perforación ha sido realizada con el uso de un taladro, aplicado desde las dos caras, 
como se puede ver en el interior de las perforaciones acabadas o en fase de elaboración (68466a, 68953-2). Los bordes de los orificios tienen forma circular muy regular y las huellas en el interior son perfectamente concéntricas (Figura 12C).

A partir de pruebas experimentales realizadas por nosotros mismos, y de acuerdo, también, a otros estudios sobre talleres de brazaletes en piedra (Martínez, 2010), la ejecución de los elementos anulares en piedra necesitaba varias fases: la preparación de una preforma, el tallado, el piqueteado, la regularización de la superficie externa y la horadación de la parte interior, la perforación central, la reducción de la talla y el pulido (Martinez, 2010, pp. 47-48). En los fragmentos de elementos anulares (categoría III, grupo 2, subgrupo 1) que pertenecían a adornos acabados la única fase que podemos constatar es el excelente acabado, ya que los artefactos lucen una superficie completamente pulida, aunque en algunos casos se han podido observar en la parte exterior de la pieza trazos paralelos y en la interior estrías paralelas y concéntricas propias de la fase de abrasión. Los dos elementos anulares en fase de elaboración nos proporcionan mucha más información. En concreto, el fragmento 63735 seguramente se fracturó durante la fase de la perforación central, durante la cual se golpea con percusión indirecta en la parte central del objeto desde las dos caras de la pieza (Martínez, 2010, p. 48). En el fragmento 63735 se han detectado las huellas de la percusión directa y también huellas de abrasión atribuibles a la anterior fase de regularización y horadación. El segundo fragmento (69412), está todavía en la fase de reducción, presentando aristas muy profundas de abrasión, y en su superficie no encontramos todavía el pulido de los fragmentos finalizados.

\section{Uso}

Hemos definido las conchas de gasterópodos perforados (Neolítico Antiguo y Medio) como colgantes teniendo en cuenta la ubicación de la perforación y el número de orificios. De hecho, gracias a pruebas experimentales con conchas de las mismas especies y con el mismo grado de trasformación, ha sido posible demostrar que el objeto suspendido desplaza el eje desequilibrando la pieza. Serían, así, "elementos destacados respecto a la línea formada por un conjunto de cuentas insertadas" coincidiendo con la definición de R. Maicas (2007, p. 173). Sólo en uno de los adornos ha sido posible identificar trazas de uso en el orificio de perforación. Se trata de una pequeña muesca seguramente determinada por el hilo o cuerda de suspensión. En el resto de los artefactos es imposible distinguir el lustre producido por el uso de aquél generado por la acción del mar (Figura 13A).

En la cara inferior y en los márgenes del colgante subrectangular 612579 (Neolítico Antiguo) y del colgante rectangular 69508 (Neolítico Medio) hay manchas de pulido, posiblemente derivadas del roce de los objetos de adorno con las vestimentas o la piel de quienes los llevaban. El mismo brillo se localiza también en la superficie de la perforación, originado, en este caso, por el roce de una cuerda o un hilo de suspensión. Además, mientras que la fractura del orificio del colgante subrectangular 612579 (Neolítico Antiguo) se puede considerar reciente, la del artefacto 68377 (Neolítico Medio) se ha producido en momentos anteriores. Lo que más destaca es que, después de esa rotura, se consideró oportuno reparar el objeto realizando un segundo agujero para poderlo mantener en uso y regularizando los bordes de la fractura. Sin embargo, aun estando seguros de la regularización tras la fractura, no podemos descartar el hecho que este artefacto en origen hubiera tenido dos agujeros, realizados contemporáneamente para poderlo utilizar como separador de cuentas. En un segundo momento, después de la rotura de una de las dos perforaciones, el objeto pudo ser restaurado para una nueva función, la de colgante. En un caso o en el otro se debe considerar que fue un objeto muy preciado. En el colgante subrectangular 613854 (Neolítico Antiguo) no se han detectado trazas de uso, lo que posiblemente pueda imputarse al mal estado de conservación del artefacto. 


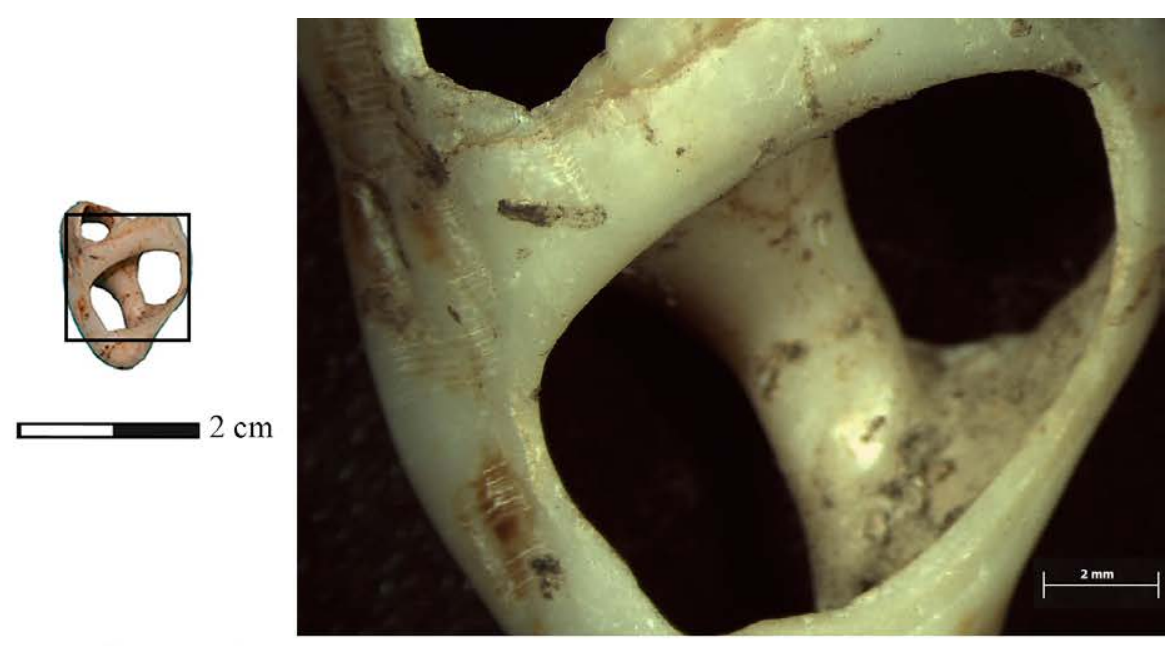

A

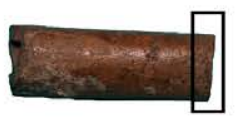

B
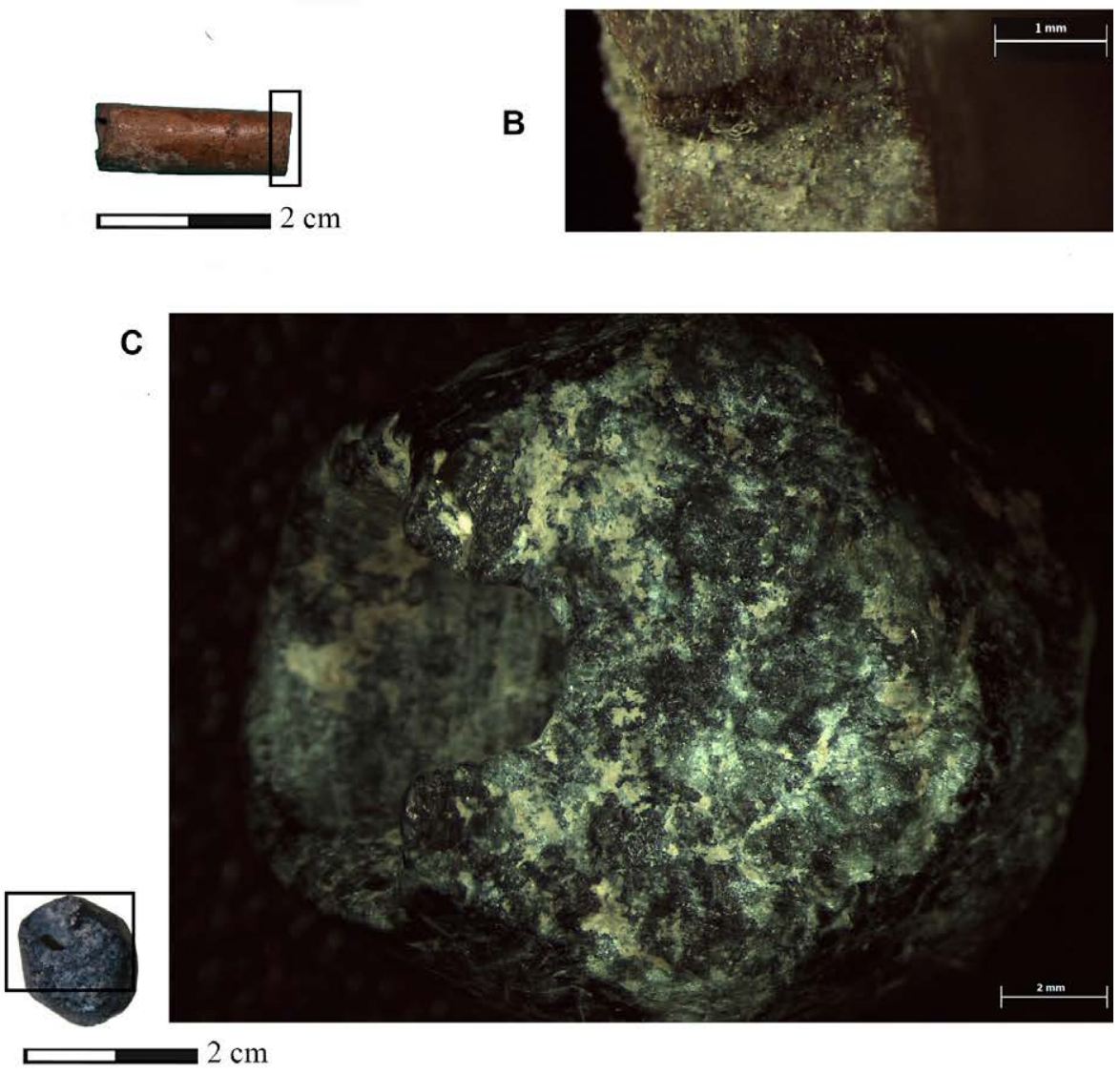

Figura 13. Desgaste en la superficie A) del colgante en concha (61128299); B) muesca de uso en el colgante bitroncocónico (66320); C) traza de uso en la cuenta cilíndrica (6106829).

Los colgantes de lágrima estudiados presentan un mal estado de conservación, aunque ha sido posible identificar una muesca de uso bien marcada en el orificio de uno de éstos, 69678 (Neolítico Medio). Este grupo de artefactos, conocido en varias regiones europeas, realizado en concha, piedra y hueso desde el Neolítico hasta el Bronce (Pau, 2016, p. 652), para muchos investigadores representa la forma de los dientes atrofiados de los ciervos, elementos que se considera transmitían una fuerte carga simbólica (con mensajes de virilidad, fecundidad y supervivencia) (Bordreuil, 1966). 
Entre las cuentas en conchas obtenidas de escafópodos (Neolítico Final) sólo el ejemplar completo (610682) nos ha proporcionado datos sobre su uso, habiéndose podido observar al microscopio el lustre en los bordes y la presencia de una profunda muesca. Esto nos indica que el pequeño adorno había empezado a consumarse por el uso, debido al roce con el hilo o la cuerda que lo suspendía, y por el contacto con los otros elementos que formaban un adorno compuesto (collar o pulsera). Este tipo de colgantes ha sido considerado símbolo del sexo masculino aunque en asociación (y esto no es nuestro caso) con las conchas de Cypraea consideradas símbolo del sexo femenino (Barge, 1982, p. 83).

Las cuentas discoidales (611032, 610180a, del Neolítico Medio; 68953a, 69070, 67948a, 63682, del Neolítico Tardío; 68517, 68502c del Neolítico Final) presentan desgastes en la totalidad del contorno de las perforaciones, más evidentes en los dos ejemplares manufacturados en concha y en el artefacto en esquisto, como consecuencia del paso de un cordel. Además, los artefactos 610180a, 69070, 67948a, 63682, 68517 y 68502c presentan los vértices desgastados $\mathrm{y}$, a veces, redondeados, lo que siguiere un uso continuado. Como testimonian los ejemplos etnográficos y arqueológicos, estos grupos de cuentas se utilizarían en la elaboración de pulseras o collares, aunque no podemos descartar su uso como adornos cosidos en las vestimentas como testimonian pueblos más recientes, como los Turkana de Kenya y los esquimales de la Bahía de Hudson (Barciela, 2008, p. 81)

La cuenta cilíndrica 612638 (Neolítico Antiguo) presenta las extremidades pulidas por el roce de la cuenta con los otros elementos del mismo collar o pulsera, mientras que la cuenta en hueso 6106829 (Neolítico Medio) presenta una profunda muesca en el borde producida por el método de sujeción (Figura 13B).

Las cuentas bitroncocónicas presentan desgastes intensos en los bordes de la perforación. Probablemente los adornos habían estado colgados o cosidos en modo individual y eso determinaría la formación de la muesca de uso por el roce continuo en el mismo punto (Figura 13C).

Los elementos anulares no presentan huellas de uso sino sólo huellas tecnológicas, como hemos ya comentado. Teniendo en cuenta los tamaños habituales de las extremidades del cuerpo humano en las diferentes edades de los individuos, podemos sugerir que el adorno 65226 de la categoría III, grupo I (Neolítico Medio) con diámetro interno de 1 $\mathrm{cm}$ sería un colgante, un elemento utilizado en la decoración del cabello o vestimenta o un pequeño anillo, que llevarían en los dedos de manos o pies individuos de constitución grácil o edad infantil. En el artefacto no se han encontrado huellas de uso que puedan ayudarnos a discriminar entre esos posibles usos. Los elementos anulares (Neolítico Antiguo/Neolítico Tardío) en piedra o en concha (categoría III grupo 2) que presentan un diámetro interno entre los 4 y $10 \mathrm{~cm}$ se identifican tradicionalmente como brazaletes. Están conformados por una sola pieza rígida, distinguiéndose de los artefactos compuestos definidos como pulseras por R. Maicas (2007, p. 167), que no han sido localizados en nuestro conjunto. Para nosotros, el término más apropiado, sin embargo, sería el de pulseras porque estos elementos anulares, por su rigidez y dimensiones sólo podían haber sido utilizados para decorar las muñecas. Esto nos llevaría también a rechazar su uso como tobilleras. Sin embargo, para objetos contemporáneos de contextos cercanos se ha sugerido su uso en los tobillos, a partir de una representación de M. Pellicer de sus hallazgos en la Cueva del Agua (Alhama, Granada) en la que se localizó un artefacto en piedra en el tobillo de un individuo (Molina, 1983, p. 74). Constituyen además una excepción, a este dominio de piezas monolíticas que consideramos pulseras, los 5 fragmentos $(613726,613708$, del Neolítico Antiguo; 64924, 68466a, 68466b, del Neolítico Medio) en material lítico con perforación que pudieran haber sido utilizados entrelazados alrededor de las muñecas o de los 
antebrazos con cuerdas o hilos vegetales o de piel, como confirmarían los paralelos etnográficos (Barciela, 2008). Esta misma forma de uso pudiera haber sido utilizada para sujetar a las extremidades del cuerpo porciones semicirculares de brazaletes de concha.

Resulta problemática la identificación del uso de los elementos cónicos $(612214,511569$, 610204, 6153, 65300, 64857, 68843, 68953c, del Neolítico Antiguo al Tardío), ya que no se observa en ellos ningún sistema que hubiera permitido suspenderlos como colgantes o cuentas, ni se ha identificado en su superficie restos de ninguna sustancia orgánica utilizada como pegamento ni se han podido observar al microscopio trazas de uso convincentes. Por lo tanto podemos sólo conjeturar que estas piezas hubieran sido utilizadas como objetos de adorno personal para decorar el cuerpo o las vestimentas, no descartando la posibilidad de que su uso hubiera podido ser muy diferente: piezas de juego, decoraciones de mobiliario, elementos rituales, etc.

La morfología y el tipo de decoración nos ha hecho clasificar el grupo IV de artefactos (64173, 66109 y 66339 del Cobre Antiguo) como alfileres o cabezas de alfiler, utilizados para decorar y sujetar el pelo o para adornar o cerrar algún tipo de vestimenta, si bien no se ha encontrado ninguna huella de uso en las piezas.

A los elementos dentados se han atribuido varias funciones: instrumentos utilizados para decorar la cerámica, útiles usados para las actividades textiles o la limpieza de pieles, objetos de adorno personal en sentido estricto como colgantes o peinetas para el cabello e incluso hay quienes los consideran amuletos o elementos dotados de una fuerte carga simbólica para indicar diferenciación social o profesional (Castro, 1988; Pascual, 1998, p. 86). Sin embargo, la interpretación tradicional los identifica como peines empleados para el aseo personal, para arreglar y limpiar el cabello. Nuestro artefacto (68495) (Neolítico Final) presenta una serie de surcos en la base de los dientes visibles observándolo al microscopio, que, según otros investigadores (Altamirano, 2014, p. 158) que han estudiado materiales del mismo yacimiento, habían podido haber sido producidos por la combinación de grasa, suciedad y polvo del cabello durante el peinado cotidiano, haciendo comparaciones con casos etnográficos de Europa Central y del Este de época moderna y contemporánea. Esta teoría viene puesta en duda por el tamaño reducido de los dientes del artefacto estudiado. De hecho, el diente conservado completo mide sólo $5 \mathrm{~mm}$.

\section{Discusión y conclusiones}

El estudio de los objetos de adorno personal correspondientes al Neolítico y Calcolítico Precampaniforme del yacimiento de Los Castillejos de Montefrío, recuperados durante las intervenciones arqueológicas de los años 90 del siglo XX, ha permitido identificar seis categorías diferentes de adornos a partir de criterios morfofuncionales: colgantes, cuentas, elementos anulares, elementos cónicos, alfileres y elementos dentados. Siguiendo variaciones dimensionales o de materia prima, principalmente, a veces estas categorías se han dividido en grupos, subgrupos y tipos. Los grupos de adornos son los mismos que se hallaron en los mayores yacimientos andaluces durante las mismas fases culturales, pero el estudio nos ha permitido clarificar la cronología de estos objetos e indirectamente corregir algunas atribuciones cronológicas de contextos sin estratigrafía.

Se ha podido establecer (Tabla 2) que en los niveles más antiguos (Neolítico Antiguo, 5400-5000 a.C.) se usaban colgantes de concha entera, colgantes rectangulares, cuentas cilíndricas, elementos cónicos, brazaletes en piedra (grupo 2, subgrupo 1 tipo 1, 2 y 3). En el periodo sucesivo (Neolítico Medio, 5000-4880 a.C.) siguen apareciendo los colgantes de concha entera, los colgantes rectangulares, las cuentas cilíndricas, los 
elementos cónicos y los elementos anulares en piedra (grupo 2, subgrupo 1 tipo 1, 2 y 3), mientras que aparecen por primera vez los colgantes de lágrima, las cuentas discoidales, el grupo 1 de elementos anulares en piedra y, más significativamente, los elementos anulares en concha (grupo 2, subgrupo 2). En el Neolítico Tardío (44003600 a.C.) encontramos colgantes de lágrima y rectangulares, cuentas discoidales y elementos anulares en concha y piedra (grupo 2, subgrupo 2; grupo 2, subgrupo 1, tipo 1; grupo 2 subgrupo 1, tipo 3). En los niveles más recientes del Neolítico (Neolítico Final, 3600-3300 a.C.) se conservan cuentas de concha entera, cuentas discoidales, elementos dentados y brazaletes de Pectunculus. Aunque en niveles de este periodo se han encontrado también elementos anulares en piedra (grupo 1, subgrupo 2, tipo 3), como hemos dicho, los contextos en los que han aparecido (Sector F) se hallaban profundamente alterados por las fosas, lo que unido al escaso número de ejemplares nos lleva a considerarlos intrusiones. En el Cobre Antiguo (3300-3000 a.C.) aparecen los alfileres y las cuentas bitroncocónicas, continuando estas últimas en el Cobre Pleno (3300-2550 a.C). Como hemos señalado para el Neolítico Final, los escasos elementos anulares en piedra (grupo 1, subgrupo 2, tipo 3) localizados a niveles del Cobre Antiguo deben considerarse intrusiones.

Se puede observar que varios tipos son recurrentes, aparecen en las fases más antiguas desaparecen y vuelven a encontrarse en las fases más recientes, mientras que otras caracterizan sólo algunos periodos culturales. En el caso de grupos de elementos hallados en escaso número no podemos extraer conclusiones definitivas, en particular cuando los objetos, como los colgantes en concha, aparecen en toda la prehistoria reciente en ámbito europeo. Al contrario, pueden ser significativos los resultados obtenidos examinando los grupos de artefactos como los elementos anulares en piedra y en concha de los cuales se conserva un alto número de ejemplares (112 elementos). Se observa que los elementos anulares en piedra caracterizan el Neolítico Antiguo, Medio y Tardío (aunque hay intrusiones en periodos posteriores), mientras que los brazaletes en concha son más recientes, aparecen por primera vez en el Neolítico Medio y continúan en todo el Neolítico Reciente. De la cantidad de elementos recuperados y la continuidad en la ocupación de los Castillejos, salvo el hiato del final del Neolítico Medio (Molina et al., 2017), esta distribución cronológica de los brazaletes de concha puede tener importantes implicaciones para la datación de las primeras fases de utilización de contextos megalíticos donde tales brazaletes suelen ser frecuentes (Leisner y Leisner, 1943; Siret y Siret, 1890). Podemos plantear que muchos sepulcros megalíticos estuvieran ya en uso en el Neolítico Final, si no antes, lo que tiene implicaciones también para asegurar una construcción neolítica de estas tumbas, aun cuando las fechas disponibles hasta ahora sean casi todas calcolíticas (Balsera et al., 2015). Además hay tipologías que están presentes sólo en los niveles más recientes, tales como las cuentas bitroncocónicas.

En algún caso se puede observar una evolución morfológica, como en los colgantes de forma rectangular donde se ha constatado la trasformación del perfil. Desde formas muy irregulares en las etapas más antiguas (fase estratigráfica 2) se pasará a formas subrectangulares con los ángulos redondeados (fase estratigráfica 4 y 11) y finalmente a formas más rectas en los ejemplares más recientes (fases estratigráficas 13 y 14) ya atribuibles al Neolítico Reciente.

Es importante observar que los objetos de adorno personal del Neolítico y del Calcolítico Precampaniforme de los Castillejos de Montefrío encuentran parecidos formales con los artefactos hallados en otros yacimientos andaluces contemporáneos, demostrando la existencia de contactos entre las varias comunidades culturales, el desarrollo de tradiciones coetáneas y contactos entre las distintas comunidades que ocuparon la región. Además las categorías de adornos del yacimiento de los Castillejos, son formas típicas y recurrentes en las fases neolíticas y calcolíticas europeas. 
Los colgantes y las cuentas en concha son elementos utilizados en diferentes periodos prehistóricos y en varios contextos distribuidos por toda la geografía europea. En particular podemos puntualizar que se han encontrado colgantes obtenidos desde el exosqueleto de un Conus Mediterraneus, similares al artefacto estudiado, en cuevas con ocupación neolítica de Andalucía como la Cueva de Nerja (Adán, 1987), la Cueva del Hoyo de la Mina (Málaga) (Teruel, 1986), la Cueva de las Ventanas (Piñar) (Salvatierra, 1980), y algunos yacimientos al aire libre, como el Peñón de la Reina (Alboloduy) (Maicas, 2007, p. 174). Esto indica la atribución genérica de nuestros hallazgos al Neolítico Antiguo y Medio. Lo mismo se puede decir de la Columbella rustica, que se ha encontrado en diferentes yacimientos neolíticos de Andalucía (Maicas, 2007, p. 174) como las Macolijas (Alfacar) (Teruel, 1986), la Cueva de Nerja (Adán, 1987) y la Cueva del Hoyo de la Mina (Málaga) (Teruel, 1986).

Los colgantes rectangulares o subrectangulares presentan una amplia distribución en Europa. En España encontramos ejemplares confeccionados en piedra, hueso o en concha en el País Valenciano, Murcia y en el Valle del Ebro (Pascual, 1998, p. 141). Aunque las referencias son escasas, se han referido hallazgos de colgantes de forma subrectangular también en Andalucía en la Cueva de la Carigüela (Píñar) y en la Cueva de los Murciélagos (Albuñol) (Maicas, 2007, p. 178), y en este último caso la disponibilidad de dataciones sobre cestillos de esparto (Cacho, Papí, Sanchez-Barriga y Alonso, 1996), sugiere una fecha del Neolítico Medio e inicios del Reciente.

Los colgantes de lágrima aparecen, aunque en material malacológico y no en piedra como los ejemplares estudiados aquí, en varios contextos neolíticos de Andalucía, como la Cueva el Toro (Antequera) (Goñi, 2004), la Cueva del Tesoro y Cueva Tapada (Torremolinos) (Maicas, 2007, p. 178). Estos pequeños adornos aparecen también en varios contextos europeos. En la Península Italiana se ha hallado objetos parecidos en piedra (Bordeuil, 1966, p. 255) y además en cerámica en el Véneto datados, sin embargo, en el Bronce inicial (Ferrarese Ceruti, 1997, p. 360). Objetos en concha proceden de Arene Candide (Liguria) (Bernabó Brea, 1958, lám. XLIV.17 n5), y de Is Calitas (Soleminis, Cerdeña) (Manunza et al., 2005, p. 145). En piedra se han localizado muchos colgantes de esta forma también en el sur de Alemania y en Francia (Bordreuil, 1966, p. 255). Los elementos cónicos en piedra del yacimiento de Los Castillejos son piezas muy singulares, para las cuales encontramos paralelos formales con un artefacto obtenido de una valva de un glicimérido encontrado en el enclave neolítico del Castillo de Doña Mencía (Córdoba) (Martínez, Jibaja, Liébana, Muñiz y Rodríguez, 2015, p. 225).

Las cuentas discoidales se conocen en toda el área europea, pudiéndose citar los centros de producción en concha localizados en el Ariège, en el Herault y en Charante Marítimo en Francia (Ferrarese Ceruti, 1997, p. 334; Laporte, 1997), y los centros de producción de cuentas y colgantes en talco (esteatita) en la Península Italiana, como el de Puzzolente, (Livorno) (Sammartino, 1990) y el de la Pianaccia de Suvero, (La Spezia) (Maggi, 1990). En la Península Ibérica este grupo de cuentas se encuentra en varias regiones, en particular en la Comunidad Valenciana, en Cataluña y en Andalucía. Los ejemplos más cercanos en el tiempo y en el espacio a las pequeñas cuentas discoidales en concha estudiadas aquí, se encuentran en la Cueva de Los Murciélagos (Albuñol) (Siret y Siret, 1890, figura 126), en la Cueva del Agua del Prado Negro (Iznalloz) (Navarrete y Capel, 1979), y en la Cueva de los Toyos (Siret y Siret, 1890, pp. 23-27, f.2). Este último caso es muy interesante porque los adornos se encontraron juntos a hojas y utensilios en sílex y en asociación con los colgantes de lágrima en el interior de un recipiente con decoración impresa. El hallazgo se interpretó como el ajuar de un fabricante de objetos de adorno personal (Pascual, 1998, p. 118). La cuenta discoidal en material lítico 6111032 recuerda en su morfología los artefactos hallados en la necrópolis del rio Gor (Pau, 2015). 
Las cuentas cilíndricas constituyen un grupo de adornos conocidos en Europa en un amplio periodo cronológico, por lo menos hasta la Edad del Bronce (Maicas, 2007, p. 183; Pascual, 1998, p. 121).

La cuentas bitroncocónicas en material lítico recuerdan los ejemplares valencianos de la Pastora y de Or (Pascual, 1998, p. 124).

Elementos anulares (categoría III, grupo 1) Neolíticos y Calcolíticos han sido documentados en varios contextos europeos en Francia (Barge, 1982), en Italia (Bernabó Brea, 1958; Pascual, 1998) y en la Península Ibérica (Comunidad Valenciana, Alto Aragón, áreas centro-septentrionales de Cataluña, Portugal, y Andalucía) (Pascual, 1998, p. 154). De hecho el elemento anular en hueso de forma abultada 65226 muestra una morfología recurrente en Andalucía oriental en todas las fases del Neolítico. Artefactos del mismo grupo se hallaron en las cuevas de Carigüela (Píñar), Mármoles y Huerta Anguita (Priego) (Pascual, 1998, p. 156), Murcielagos (Zueros) (Pascual, 1998, p. 156), Agua (Alhama) (Salvatierra, 1982, p. 81) y Nerja (Pascual, 1998, p. 156). Los elementos anulares en piedra, definidos generalmente como brazaletes (subtipo $1,2,3)$ aparecen ya en yacimientos protoneoliticos de los Zagros, en la zona norte de Irak, en el Neolítico Preceramico de Palestina, en el Neolítico Antiguo de Anatolia, en contextos neolíticos precerámicos chipriotas y en el Neolítico griego (Pascual, 1998, p. 161). En zonas más cercanas se pueden citar hallazgos en contextos neolíticos de la Península Italiana (Tanda, 1977), Francia (Barge, 1982; Courtin y Gutherz, 1976) y la misma Península Ibérica (Martínez, 2016).

Debemos retomar aquí la discusión anterior y señalar que nuestro estudio ha demostrado que este tipo de objetos se localiza al menos, en niveles correspondientes al Neolítico Antiguo, Medio y Tardío, a diferencia de lo que se había propuesto a partir de la secuencia de la Carigüela donde los brazaletes de pizarra (subtipo 1) se encuentran sólo en el Neolítico Medio y Final y los de caliza (subtipo 2,3) se distribuyen por todos los estratos (Pascual, 1998, p. 161). Dados los problemas de la secuencia de la Carigüela, obtenida en las excavaciones antiguas (Pellicer, 1964, 1992), creemos que las precisiones del material de los Castillejos son atendibles. El amplio número de objetos estratificado implica además que su fabricación y uso, contra lo que se ha propuesto (Martínez, 2016), superó el fin del denominado Neolítico Medio y alcanzó los primeros siglos del IV Milenio a.C. Esto tiene implicaciones también en dos aspectos sobre los que se ha discutido recientemente: la relevancia del hiato localizado en algunos yacimientos andaluces en contextos de mediados del V Milenio a.C. (Martínez, 2016; Molina et al., 2017) y el momento y alcance de las transformaciones que tuvieron lugar con el advenimiento del denominado Neolítico Reciente a fines del V Milenio a.C. (Molina, Cámara, Afonso y Spanedda, 2016). Al igual que se ha referido para la industria lítica tallada y para la cerámica, la industria lítica pulida (en concreto los brazaletes) en la secuencia de Los Castillejos, indica que las transformaciones en las industrias tuvieron lugar, de forma progresiva, a fines del V Milenio a.C., siguiendo las lentas transformaciones que tuvieron lugar en otras esferas socioeconómicas (Molina et al., 2016).

Hay que añadir que los brazaletes finos están muy presentes en los yacimientos de la provincia de Granada, estando menos representados en las de Málaga, Almería y Córdoba. En general, los brazaletes anchos son los más numerosos en Andalucía durante el Neolítico, muchos de ellos decorados (Pascual, 1998, p. 161). Sin embargo estos ejemplares decorados no aparecen en Montefrío, tal vez por corresponder al periodo donde se constata el hiato en este yacimiento, si bien en este caso sería extraña su ausencia total de los niveles inmediatamente posteriores. Los brazaletes de concha conservados en las fases estratigráficas del Neolítico Medio y Reciente de Los Castillejos de Montefrío están entre los objetos de adorno más característicos de la 
Europa neolítica, manufacturados utilizando conchas diferentes no sólo el Glycimeris. En Italia estos ornamentos se encuentran en particular en la zona septentrional, y son más escasos en el sur y en las islas. Se conocen artefactos de este tipo también en Francia, en Suiza, en Grecia (Micheli, 2010) y en Portugal (Pascual, 1998). En el resto de la Península Ibérica presentan una distribución generalmente costera, sobre todo mediterránea, aunque con casos de penetración hacia el interior (Pascual, 1998, p. 163; Maicas, 2007, p. 167). En particular en Andalucía este tipo de objetos está presente en varios yacimientos, como la Sala de la Mina de la Cueva de Nerja (Pascual, 1998, p. 163), la necrópolis del río Gor (tumba 102 del llano de Olivares) (Pau, 2015, p. 66), el sepulcro 8 de la necrópolis de los Bermejales (Arribas y Ferrer, 1997) y otras muchas tumbas megalíticas de Almería (Siret y Siret, 1890). Como hemos dicho, la concreción cronológica de Montefrío permite situar la construcción y primer uso de estas tumbas en el Neolítico. Las cabezas de alfiler estudiadas pertenecen todas al Cobre Antiguo, el tipo espátula es muy conocido en Europa desde el Neolítico Medio hasta la Edad de los Metales (Pascual, 1998, p. 113) mientras el tipo 2 con cabeza acanalada es típico de la Edad del Cobre, contando con numerosos ejemplares también en época Campaniforme. Es ampliamente recurrente en la Península Ibérica con ejemplos en el estuario del Tajo, Levante, Murcia y Portugal y se conocen contextos con estos objetos también en Granada. Esta última tipología de alfileres viene muchas veces asociada cronológicamente a los colgantes con incisiones o glóbulos (Nieto, 1959).

Los elementos dentados, definidos como peines, se difunden entre el Neolítico Inicial y la Edad del Bronce (Castro, 1988). Son artefactos de amplia difusión geográfica, numerosos en Próximo Oriente, en Egipto y en Italia mientras que son escasos en Francia y en Alemania (Maicas, 2007, p. 157). En la Península Ibérica, los peines constituyen una categoría de adornos muy conocida en la prehistoria. Se encuentran ejemplares en madera, hueso y marfil hasta la Edad del Bronce, en varios yacimientos como Los Millares (Santa Fe de Mondújar), El Oficio (Cuevas del Almanzora), El Argar (Antas), Fuente Álamo (Cuevas del Almanzora), Mola d'Agres (Agres), San Antón (Orihuela), Cabezo Redondo (Villena), Blanquizares (Lebor) continuando su distribución por el resto de Levante y el Valle del Ebro (López, 2011, pp. 476-477; Maicas, 2007, pp. 156-157). Nuestro ejemplar (68495) del Neolítico Final, más antiguo que todos los citados, presenta semejanzas formales con otros artefactos andaluces, en particular con los granadinos de Cueva Alta de Montefrío (Moreno, 1982, figura 3; Tarradell, 1952) y con los hallados en las excavaciones de los años 1971 y 1974 por el Departamento de Prehistoria y Arqueología de la Universidad de Granada en los Castillejos (Altamirano, 2014, p. 361), además de con los de Los Millares (Leisner y Leisner, 1943, láminas 9 y 10).

El estudio de la materia prima utilizada para confeccionar los adornos indica el uso de materiales locales y alóctonos. Las conchas usadas para la fabricación de los objetos de adorno personal estudiados pertenecen a moluscos presentes en las aguas del Mediterráneo y serían por lo tanto un recurso natural abundante en las costas. Teniendo en cuenta que Los Castillejos de Montefrío se encuentra aproximadamente a unos $90 \mathrm{~km}$ del mar, se entiende que las poblaciones neolíticas y calcolíticas del yacimiento se pudieran abastecer de esta materia prima personalmente, viajando por unos días y recogiendo las conchas post mortem en la orilla del mar. También es posible que esta gente consiguiera las conchas a través de poblaciones que vivían en la costa, por intercambio de sus formas naturales o ya modificadas antrópicamente, y sueltas o unidas en adornos complejos (collares, pulseras, etc.). Los resultados de los análisis de los adornos en hueso coinciden con las especies documentadas en los estudios arquezoológicos sobre los restos óseos de animales (Riquelme, 1996; Uepermann, 1979), lo que sugiere una producción local de los objetos de adorno, aunque no podemos descartar que algunos de los artefactos pudieran haber sido importados ya manufacturados. Los análisis de los adornos confeccionados en piedra indican 
el uso de materiales autóctonos que proceden de la geología local, en particular del complejo Alpujárride, en la zona Subbética y Nevado-Filábride (Carrión y Gómez, 1983). La riqueza de estos materiales en las zonas limítrofes al yacimiento nos explica por qué se eligió el uso de material lítico para la manufactura de algunos artefactos como los colgantes de lágrima y los elementos cónicos y no de material malacológico como se atestigua en otros contextos. Para los elementos anulares en piedra, aunque se han encontrado sólo dos piezas en fase de elaboración, se considera que la facilidad en el aprovechamiento de la materia prima y el gran número de elementos hallados durante las excavaciones son datos suficientes para proponer la existencia de centros de producción en el mismo poblado (si bien no en la zona excavada) o la presencia de centros estrechamente conectados con el yacimiento. Todos los rasgos técnicos implican, en cualquier caso, una alta destreza artesanal en el trabajo de la piedra durante la época neolítica. El único objeto estudiado confeccionado en material con toda seguridad exótico (marfil) es el colgante subrectangular 69508 de la fase estratigráfica $11 \mathrm{~b}$. La presencia de este elemento presupone la existencia de una red de intercambios de este precioso material y la participación, directa o indirecta, de las poblaciones de Los Castillejos en el tráfico del marfil, por lo menos durante el Neolítico Medio. Queda por determinar qué tipo de marfil se utilizó en este objeto.

Desde el punto de vista de la tecnología se han podido observar generalmente las huellas de las últimas fases de elaboración y de regulación de la superficie de la pieza y también los diversos métodos utilizados para perforar los artefactos, mostrando en la mayoría de los casos un gran cuidado en la ejecución con óptimos resultados finales. En los colgantes de concha entera se puede observar un cambio en las técnicas de perforación, reconocible en las piezas estudiadas, entre las fases culturales más antiguas cuando los exoesqueletos de los moluscos se perforaban por percusión o presión y las fases a partir del Neolítico Medio cuando se constata el uso de la técnica de la abrasión. Además el hallazgo de elementos anulares en fase de elaboración ha permitido confirmar el método de elaboración de este grupo de artefactos, ya descrito a partir del estudio de otros contextos (Martínez, 2010).

A partir del estudio tipológico y traceológico ha sido posible proponer la manera de portar las diferentes categorías de artefactos. Las cuentas, los colgantes y los elementos anulares del grupo 1 se utilizarían para confeccionar adornos complejos como collares y pulseras, o para decorar la cabeza o la vestimentas, mientras que los elementos anulares del grupo 2 se utilizarían como pulseras (en su mayor parte monolíticas) para las muñecas, aunque existe la posibilidad de que los adornos de este grupo con perforaciones se pudieran aplicar en los antebrazos o en los tobillos. Hemos indicado ya la imposibilidad, considerando la escasez de datos, de identificar el uso de los elementos de forma dentada y los de forma cónica. En relación con estos últimos artefactos, en el caso de que pudiera tratarse verdaderamente de objetos de adorno corporal en sensu stricto, se propone su uso como discos en los lóbulos de las orejas, en el labio inferior o en la misma barbilla.

Además debemos tener en cuenta que los objetos de adorno personal presentan un carácter polifuncional, no sólo poseen un valor estético sino que, como elementos simbólicos, pueden presentar el valor de un individuo con respecto a un grupo, pueden estar ligados con creencias, a usos apotropaicos, profilácticos o terapéuticos (Barge, 1982; Pau, 2016). De hecho, son numerosos los estudios etnográficos que confirman estos usos (Hodder, 1979; Lock y Symes, 1999; Ray, 1975; Sanders, 2002; Strathern y Strathern, 1971), como ha sido ya subrayado por varios investigadores (Rigaud, 2011, p. 11).

Muchos de los adornos estudiados pudieron ser símbolos de identificación social o de riqueza, u objetos intercambiados durante ceremonias sociales y fiestas para 
consolidar alianzas entre familias. De hecho hay ejemplos entre los cazadores Naga de ornamentos con fuerte carga social, ya que collares y brazaletes indican el rango social de los individuos (Rigaud, 2011). El alto número de ejemplares de elementos anulares, considerados habitualmente brazaletes, puede llevarnos a interpretaciones de este tipo. Sin embargo el mismo uso del marfil, material preciado y exótico, podría indicar un intercambio para satisfacer la demanda de grupos sociales restringidos, un lento proceso que sólo se acentuará al final del Calcolítico (Pau, 2016).

La presencia de artefactos que después de la rotura no se descartaron y se repararon para mantenerlos en uso nos señala, de nuevo, la importancia que tenían estos objetos para su portador, adornos utilizados durante toda la vida por el sujeto y después de su muerte, a menudo depuestos en la sepultura como indican los hallazgos en tumbas de esta época. Sólo en los casos en que los localizamos en los poblados, como en nuestro estudio, podemos plantear que fueron trasmitidos a los hijos y las reparaciones podrían leerse en ese sentido (valor afectivo además de social). Está claro que estos ornamentos eran considerados objetos valiosos y claramente su función no era solo la de un simple objeto de adorno sino la de un objeto precioso y de prestigio para mantener la identidad y los lazos sociales.

\section{Agradecimientos}

Este estudio ha sido realizado gracias a la ayuda del Proyecto "Cronología de la consolidación del sedentarismo y la desigualdad social en el Alto Guadalquivir" (HAR2008-04577), financiado por el Ministerio de Ciencia e Innovación. 


\section{Q Referecias citadas}

»Adán, G. (1987). Industria ósea neolítica de la Cueva de Nerja. Trabajo presentando en el Congreso Internacional El Estrecho de Gibraltar, Sala de la Mina, Ceuta I.

» Afonso, J. A., Molina, F., Rodriguez, M. O., Moreno, M., Cámara, J. A. y Ramos, U. (1996). Espacio y tiempo. La secuencia en Los Castillejos de Las Peñas de los Gitanos (Montefrío, Granada). Rubricatum, I(1), 297-304.

》Altamirano, M. (2013). Hueso, hasta, marfil y concha: aspectos tecnológico y socioculturales durante el III y el II milenio a. C. En el Sur de la Peninsula Iberica. (Tesis Doctoral inédita), Universidad de Granada, España.

" Altamirano, M. (2014). Uso y mantenimiento de objetos. Botones y peines de marfil, hueso y asta de ciervo de Los Castillejos de Montefrío (Granada). Antiqvitas, 26, 155-160.

»Álvarez Fernández, E. (2006). Los objetos de adorno-colgantes del paleolítico superior y del mesolítico en la cornisa cantábrica y en el valle del Ebro: una visión europea. Salamanca: Ediciones Universidad de Salamanca.

» Arribas, A. y Ferrer, J. E. (1997). La necrópolis megalítica del Pantano de los Bermejales. Granada: Monografía Arte y Arqueología, Universidad de Granada.

»Arribas, A. y Molina, F. (1977). El poblado de Los Castillejos en las Peñas de los Gitanos (Montefrio, Granada). Resultados de las campañas de 1971-74. Trabajo presentando en el XIV Congreso Nacional de Arqueología, Vitoria, España.

»Arribas, A. y Molina, F. (1978). El poblado de Los Castillejos en las Peñas de los Gitanos (Montefrío, Granada). Campaña de excavaciones de 1971. El corte nº 1. Cuadernos de Prehistoria de la Universidad de Granada, Serie Monográfica 3. Granada: Secretariado de Publicaciones para el Departamento de Prehistoria de la Universidad de Granada.

》Arribas, A. y Molina, F. (1979). Nuevas aportaciones al inicio de la metalurgia en la Península Ibérica. El poblado de Los Castillejos de Montefrío (Granada). Trabajo presentado en Proceedings of the Fifth Atlantic Colloquium, Dublin, Irlanda.

" Balsera, V., Bernabeu, J., Costa Caramé, M., Díaz del Río, P., García, L. y Pardo, S. (2015). The Radiocarbon Chronology of Southern Spain's Late Prehistory (5600-100o Cal BC): a Comparative Review. Oxford Journal of Archaeology, 34(2), 139-156.

" Barciela, V. (2008). Adorno y simbolismo. Los adornos personales el Neolítico y Eneolítico en Villena (Alicante). Villena: Fundación Municipal “José María Soler”.

" Barge, H. (1982). Les parures du Néolithique ancien au début de l'Âge des Métaux en Languedoc. Paris: Centre National de la Recherche Scientifique.

" Bernabò Brea, L. (1958). La Sicilia prima dei greci. Milano: Il Saggiatore.

" Bonnardin, S. (2009). La parure funéraire au Néolithique ancien dans les Bassins parisiens et rhénans. Rubané, Hinkelstein et Villeneuve-Saint-Germain. París: Mémoire de la Société Préhistorique Française.

》 Bordreuil, M. (1966). Recherches sur les perles ti ailettes. Trabajo presentando en Congres Préhistorique de France, París, Francia.

" Cacho, C., Papí, C., Sanchez-Barriga, A. y Alonso, F. (1996). La cestería decorada de la cueva de los Murciélagos, (Albuñol, Granada). Complutum extra, 6(1), $105-122$. 
»Cámara, J. A., Afonso, J. A. y Molina, F. (2016). La ocupación de Las Peñas de los Gitanos (Montefrío, Granada) desde el Neolítico al mundo romano. Asentamiento y ritual funerario. En R. Pedregosa (Coord.), Arqueología e Historia de un paisaje singular. La Peña de los Gitanos, Montefrío (Granada) (pp. 17-121). Montefrío: Ayuntamiento de Montefrío, Ministerio de Cultura.

»Cámara, J. A., Molina, F. y Afonso, J. A. (2005). La cronología absoluta de Los Castillejos en Las Peñas de los Gitanos (Montefrío, Granada). Trabajo presentando en Actas del III Congreso del Neolítico en la Península Ibérica, Santander, España.

» Carrión, F. y Gómez, M. T. (1983). Análisis petroarqueológico de los artefactos de piedra trabajada durante la prehistoria reciente en la provincia de Granada. Cuadernos de Prehistoria de la Universidad de Granada, 8, 447-478.

»Castro, Z. (1988). Peines prehistóricos peninsulares. Trabajos de Prehistoria, 45, 243-258.

»Courtin, J. y Gutherz, X. (1976). Les bracelets de pierre du Néolithique méridional. Bulletin de la Société Préhistorique Française, 73, 352-369.

»De Mergelina, C. (1941-1942). La estación arqueológica de Montefrío (Granada). I: Los dólmenes. Boletín de la Sociedad de Arte y arqueología, VIII, 33-106.

»De Mergelina, C. (1946). La estación arqueológica de Montefrío (Granada). II: La acrópolis de Guirrete (Los Castillejos). Boletín de la Sociedad de Arte y Arqueología, XII, 15-26.

» Ferrarese Ceruti, M. L. (1997). Archeologia della Sardegna preistorica e protostorica. Poliedro: Nuoro.

» Gofas, S. Moreno, D. y Salas, C. (2011). Moluscos marinos de Andalucía. (Volumen 1). Málaga: Servicio de Publicaciones e Intercambio Científico, Universidad de Málaga.

» Gómez, M. (1907). Monumentos arquitectónicos de España. Madrid: Imprenta de la Gaceta de Madrid.

» Gómez, M. (1949). Monumentos arquitectónicos de la provincia de Granada. En M. Gómez, Misceláneas, Historia-Arte-Arqueología. Primera Serie. La Antigüedad (pp. 347390). Madrid: Instituto Diego Velázquez, Consejo Superior de Investigaciones Científicas.

» Góngora Martínez, M. (1991). Antigüedades prehistóricas de Andalucía (Reedición Facsímil). Granada: Universidad de Granada.

»Goñi, A. (2004). Elementos de adorno personal. En D. Martín, M. D. Cálamich y P. González (Eds.), La cueva del toro (Sierra de El Torcal, Antequera, Málaga). Un modelo de ocupación ganadera en el territorio andaluz entre el VI y II milenio A.N.E. (pp. 197-213). Sevilla: Consejería de Cultura.

"Hodder I. (1979). Economic and social stress and material culture patterning. American Antiquity, 44, 446-454.

"Laporte, L. (1997). Un site de production de parures discoïdes en coquillageau Néolitique final à Ponthezières (Saint-Georges-d'Oléron, Charante-Maritime) [CD-ROM]. Paris: Ministère de la Culture, Direction du Patrimoine, Sous-Direction de l'Archéologie.

» Leisner, G. y Leisner, V. (1943). Die Megalithgräber der Iberischen Halbinsel. Der Süden. Berlin: Römisch-Germanische Forschungen.

» Lock, A. y Symes, K. (1999). Social relations, communication, and cognition. En A. Lock y C. R. Peters (Eds.), Human Symbolic Evolution (pp. 204-232). Oxford: Oxford Science Publication.

»López, J. A. (2011): Asta, hueso y marfil: artefactos óseos de la Edad del Bronce en el Levante y Sureste de la Península Ibérica (c2500-c130o cal BC) (Serie mayor 9). Alicante: Museo Arqueológico de Alicante. 
" Maggi, R. (1990). Rocchetta Vara (La Spezia). Loc. Pianaccia di Suvero, Officina per la produzione di oggetti in steatite dell'etá del vaso Campaniforme. Bollettino di Archeologia, 1-2, 119-122.

" Maicas, R. (2007). Industria ósea y funcionalidad: Neolítico y Calcolítico en la cuenta de Vera (Almería). Madrid: Consejo Superior de Investigaciones Científicas (CSIC).

» Manunza, M. R., Sanna, I., Usai, E., Buffa, R., Caló, C. M., Floris, G., Marini, E., Lai, L., Taykot, R. H., Goddard, E. y Hollander, D. (2005). La tomba di Bonnanaro di Is Calitas. En M. R. Manunza (Ed.), Cuccuru Cresia Arta. Indagini Archeologiche a Soleminis (pp. 125-178). Dolianova: Grafica del Parteolla.

" Martínez, F. (2010). Un taller neolítico de brazaletes de piedra en la cueva de los Mármoles (Priego de Córdoba). Antiqvitas, 22, 35-55.

»Martínez, F. (2016). Un adorno reflejo de una sociedad: los brazaletes líticos del Neolitico en Iberia (VI y V milenio a. C.). Tecnología, funcionalidad y circulación. (Tesis Doctoral inédita), Universidad de Granada, España.

» Martínez, R. M., Jibaja, J. F., Liébana, J. L., Muñiz, I. y Rodríguez, A. (2015). Aportaciones a la ocupación durante el Neolitico Inicial del piedemonte del Subbético Cordobés: el enclave del Castillo de Doña Mencía (Córdoba). En V. Goncalves, M. Diniz y A. C. Sousa (Eds.), $5^{\circ}$ Congreso del Neolitico Peninsular, Estudos 6 Memorías (pp. 218-227). Lisboa: Uniarq.

" Micheli, R. (2010). Nuovi dati da vecchie collezioni: i bracciali neolitici in conchiglia di Cala Tramontana (San Domino, Isole Tremiti). Bolletino del Museo Civico di Storia Naturale di Verona, 34, 23-36.

" Molina, F. (1983). La Prehistoria. En F. Molina y J. M. Roldán (Eds.), Historia de Granada I. De las primeras culturas al Isla (pp. 11-131). Granada: Don Quijote.

» Molina, F., Cámara, J. A., Alfonso, J. A., Gámiz, J., Capel, J. y Martínez, G. (2017). Hiatus in an archaeological multilevel site: Los Castillejos in Las Peñas de los Gitanos (Montefrío, Granada). En M. Cupitò, M. Vidale y A. Angelini (Eds.), Beyond Limits. Studi in onore di Giovanni Leonardi (pp. 91-100). Padova: Università degli Studi di Padova.

» Molina, F., Cámara, J. A., Afonso, J. A. y Spanedda, L. (2016). Innovación y tradición en la Prehistoria Reciente del Sudeste de la Península Ibérica y la Alta Andalucía (c. 5500-2000 cal A.C.). En A. C. Sousa, A. Carvalho y C. Veigas (Eds.), Terra e água. Escolher sementes, invocar a deusa. Estudos em Homenagem a Victor A. Gonçalves (Estudos \& Memórias 9) (pp. 317-339). Lisboa: Uniarq.

" Moreno, M. A. (1982). Los Materiales arqueológicos del poblado de Los Castillejos y Cueva Alta (Montefrío), procedentes de las excavaciones de 1946 y 1947. Cuadernos de Prehistoria de la Universidad de Granada, 7, 235-266.

" Navarrete, M. S. y Capel, T. (1979). El material no cerámico de la Cueva del Agua de Prado Negro (Iznalloz, Granada). Cuadernos de Prehistoria de la Universidad de Granada, 4, 111-132.

» Nieto, G. (1959). Colgantes y cabezas de alfiler con decoración acanalada: su distribución en la Península Ibérica. Archivo de Prehistoria Levantina, 8, 125-145.

»Oliva, M. (2015). Aprofitament i transformació de matèries preimeres pera l'elaboració d'ornaments durant la prehistòria recent (5600-3400 cal. Ane) al nord-est de la península Iberica. (Tesis Doctoral inédita), Universitat Autònoma de Barcelona, España.

» Pascual, J. L. (1998). Utillaje óseo, adornos e ídolos neolíticos valencianos. Valencia: Diputación Provincial de Valencia. 
»Pau, C. (2011). Estudio morfológico, morfométrico y traceológico de los adornos en concha del poblado de los Castillejos en Las Peñas de los Gitanos. Trabajo presentando en el Memorial Luis Siret. I Congreso de Prehistoria de Andalucía. La tutela del patrimonio prehistórico, Junta de Andalucía, Sevilla, España.

"Pau, C. (2012). Adornos campaniformes y epicampaniformes de Cerdeña. Estudio morfológico, tecnológico y funcional. Berlín: Editorial Académica Española.

»Pau, C. (2015). Los ornamentos en materia ósea del neolítico en el poblado de Los Castillejos de Montefrío. Trabajo presentando en el V Congreso del Neolítico Peninsular, Lisboa, Portugal.

»Pau, C. (2016). Los objetos de adorno en el Mediterráneo occidental en época Campaniforme y su trascendencia social. (Tesis Doctoral inédita), Universidad de Granada, España.

» Pau, C. y Molina, F. (2015). Los botones con perforación en "V” del poblado de Los Castillejos de Montefrío. Bolletino di Archeologia, VI(1), 89-110.

»Pellicer, M. (1964). El Neolítico y el Bronce de la Cueva de la Carigüela de Píñar (Granada). Trabajos de Prehistoria XV. Madrid: Consejo Superior de Investigaciones Científicas (CSIC).

»Pellicer, M. (1992). Una visión sintética de la prehistoria de Andalucía: Neolitico- Bronce reciente. SPAL, 1, 99-105.

» Ramos, U., Afonso, J. A., Cámara, J. A., Molina, F. y Moreno, M. (1997). Trabajos de acondicionamiento y estudio científico en el yacimiento de Los castillejos en las Peñas de Los Gitanos (Montefrío, Granada). Anuario Arqueológico de Andalucía, Ill, 246-252.

» Ray, D. J. (1975). The Eskimos of Bering Strait 1650-1898. Washington D. C.: University of Washington Press.

» Rigaud, S. (2011). La parure: Traceur de la géographie culturelle et des dynamiques de peuplement au passage Mésolithique Néolithique en Europe. (Tesis Doctoral inédita), Université Bordeaux, Francia.

» Riquelme, J. A. (1996). Contribución al estudio arqueofaunístico durante el Neolítico y la Edad del Cobre en las Cordilleras Béticas: el yacimiento arqueológico de Los Castillejos en las Peñas de Los gitanos, Montefrío (Granada). (Tesis Doctoral inédita), Universidad de Granada, España.

»Salvatierra, V. (1980). Estudio del material óseo de las cuevas de la Carigüela y de la Ventana (Piñar, Cuenca). Cuadernos de Prehistoria e Arqueología de la Universidad de Granada, 5, 35-8o.

»Salvatierra, V. (1982). El hueso trabajado en Granada (Del Neolítico al Bronce). (Tesis Doctoral inédita), Universidad de Granada, España.

»Sammartino, F. (1990). Insediamenti neolitici e della prima etá dei metalli in localitá La Puzzolente (Livorno). Un'officina per la lavorazione della steatite. Rassegna di Archeologia, 9, 153-182.

»Sanders, J. M. (2002). Ethnic Boundaries and Identity in Plural Societies. Annual Review of Sociology, 28, 327-357.

» Saunders, G. D. (1991). Moluscos: introducción a las conchas y moluscos de todo el mundo. Barcelona: E. J.

»Schuhmacher, T. X. (2011). Elfenbein des Chalkolithikums und der Frühen Bronzezeit auf der iberischen Halbinsel: Ergebnisse einer interdisziplinären Forschungsprojekts. Römisch-Germanisches Zentralmuseum, Mainz, 7, 91-122. 
»Schuhmacher, T. X., Cardoso, J. L. y Banerjee, A. (2009). Sourcing African Ivory in Chalcolithic Portugal. Antiquity, 83, 983-997.

» Siret, E. y Siret, L. (1890). Las primeras edades del metal en el Sudeste de España. Barcelona: Heinrich.

» Strathern, A. y Strathern, M. (1971). Self-decoration in Mount Hagen. Londres: Duckworth.

» Taborin, Y. (2004). Langage sans parole, La parure aux temps préhistoriques. París: La Maison des Roches.

» Tanda, G. (1977). Gli anelloni litici Italiani. Preistoria Alpina, 13, 111-155.

» Tarradell, M. (1947). Un yacimiento de la primera Edad del Bronce en Montefrío, Granada. Avance de los resultados de las últimas excavaciones efectuadas en Las peñas de los Gitanos. Boletín Arqueológico del Sudeste Español, (8-11), 52-55.

" Tarradell, M. (1952). Edad del Bronce en Montefrío (Granada). Resultados de las excavaciones en yacimientos de Las Peñas de los Gitanos. Ampurias, XIV, 49-8o.

» Teruel, M. S. (1986). Objeto de adorno en el Neolítico de Andalucía oriental. Síntesis tipológica. Cuadernos de Prehistoria de la Universidad de Granada, 11, 9-26.

»Uerpmann, H. P. (1979). Informe sobre los restos faunísticos del corte $\mathrm{n}^{\circ}{ }^{1}$. En A. Arribas y F. Molina (Eds.), El poblado de “Los Castillejos" en Las Peñas de los Gitanos (Montefrío, Granada). Campañas de excavaciones de 1971. El corte n 1 Cuadernos de Prehistoria de la Universidad de Granada. Serie Monográfica 3 (pp.153-168). Granada: Editorial Universidad de Granada.

» Vanharen, M. y D’Errico, F. (2001). La parure de l'enfant de la Madeleine (Fouilles Peyrony). Un nouveau regard sur l'enface au Paléolithique supérieur. Paleo, 13, 201-240. 